\title{
Distinct roles for the RNA-binding protein Staufen 1 in prostate cancer
}

Kristen A. Marcellus ${ }^{1,2+}$, Tara E. Crawford Parks ${ }^{1,2+}$, Shekoufeh Almasi ${ }^{1,2}$ and Bernard J. Jasmin ${ }^{1,2^{*}}$

\begin{abstract}
Background: Prostate cancer is one of the most common malignant cancers with the second highest global rate of mortality in men. During the early stages of disease progression, tumour growth is local and androgendependent. Despite treatment, a large percentage of patients develop androgen-independent prostate cancer, which often results in metastases, a leading cause of mortality in these patients. Our previous work on the RNAbinding protein Staufen 1 demonstrated its novel role in cancer biology, and in particular rhabdomyosarcoma tumorigenesis. To build upon this work, we have focused on the role of Staufen1 in other forms of cancer and describe here the novel and differential roles of Staufen 1 in prostate cancer.

Methods: Using a cell-based approach, three independent prostate cancer cell lines with different characteristics were used to evaluate the expression of Staufen 1 in human prostate cancer relative to control prostate cells. The functional impact of Staufen1 on several key oncogenic features of prostate cancer cells including proliferation, apoptosis, migration and invasion were systematically investigated.

Results: We show that Staufen1 levels are increased in all human prostate cancer cells examined in comparison to normal prostate epithelial cells. Furthermore, Staufen1 differentially regulates growth, migration, and invasion in the various prostate cancer cells assessed. In LNCaP prostate cancer cells, Staufen1 regulates cell proliferation through mTOR activation. Conversely, Staufen 1 regulates migration and invasion of the highly invasive, bone metastaticderived, PC3 prostate cells via the activation of focal adhesion kinase.

Conclusions: Collectively, these results show that Staufen 1 has a direct impact in prostate cancer development and further demonstrate that its functions vary amongst the prostate cancer cell types. Accordingly, Staufen 1 represents a novel target for the development of much-needed therapeutic strategies for prostate cancer.
\end{abstract}

Keywords: Prostate cancer, Staufen1, RNA-binding proteins, Invasion, Migration, Proliferation

\section{Background}

Prostate cancer (PC) is one of the most common malignant cancers with the second highest rate of mortality in men worldwide [1-4]. Despite improved scientific knowledge surrounding the underlying molecular mechanisms

\footnotetext{
* Correspondence: jasmin@uottawa.ca

${ }^{\dagger}$ Kristen A. Marcellus and Tara E. Crawford Parks contributed equally to this work.

'Department of Cellular and Molecular Medicine, Faculty of Medicine, University of Ottawa, 451 Smyth Road, Ottawa, Ontario K1H8M5, Canada

${ }^{2}$ The Eric J. Poulin Centre for Neuromuscular Diseases, Ottawa, Ontario, Canada
}

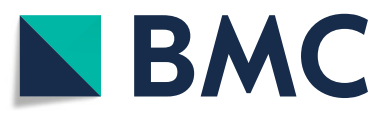

(c) The Author(s). 2021 Open Access This article is licensed under a Creative Commons Attribution 4.0 International License, which permits use, sharing, adaptation, distribution and reproduction in any medium or format, as long as you give appropriate credit to the original author(s) and the source, provide a link to the Creative Commons licence, and indicate if changes were made. The images or other third party material in this article are included in the article's Creative Commons licence, unless indicated otherwise in a credit line to the material. If material is not included in the article's Creative Commons licence and your intended use is not permitted by statutory regulation or exceeds the permitted use, you will need to obtain permission directly from the copyright holder. To view a copy of this licence, visit http://creativecommons.org/licenses/by/4.0/ The Creative Commons Public Domain Dedication waiver (http://creativecommons.org/publicdomain/zero/1.0/) applies to the data made available in this article, unless otherwise stated in a credit line to the data. and risk factors associated with $\mathrm{PC}$, prognosis remains poor for advanced PC [5]. The high mortality rate associated with $\mathrm{PC}$ is a result of aggressive migration and invasion of PC cells [6]. PC develops from prostatic intraepithelial neoplasia (PIN), by means of progressive changes in normal prostatic epithelial cells to premalignant lesions $[7,8]$. PC is often detected by a combination of testing for prostate-specific antigen, where levels $>4 \mathrm{ng} / \mathrm{ml}$ indicate an increased risk of prostate cancer, and tissue biopsy $[5,9]$.

Initially, patients diagnosed during the early stages of $\mathrm{PC}$, have an androgen-dependent tumour that is 
confined to the prostate capsule. Primary treatment involves radiation therapy or prostatectomy [4, 10, 11]. However, if the cancer spreads outside of the prostate, androgen deprivation therapy is required [10-12]. Unfortunately, androgen ablation therapy eventually fails and the majority of patients progress to castration-resistant prostate cancer (CRPC), in a median of 12 to 18 months after androgen deprivation therapy [10, 12]. Given the poor prognosis of advanced PC, there is a strong need for additional research focused on the molecular mechanisms underlying the progression of CRPC.

A key hallmark of CRPC is the ability to invade tissues and establish metastatic sites [13]. As metastatic disease is the leading cause of death in cancer patients, investigation into the process of tumour invasion and migration is essential for identifying new therapeutic targets [13]. Metastasis is the formation of a secondary tumour at a distant site from the primary lesions [14, 15]. The process of metastasis is multifaceted. It begins with a cancer cell breaking away from the primary tumour and infiltrating the circulatory system, followed by invasion of a different tissue and growth at that secondary site $[14,16]$. The cellular processes implicated in metastasis are regulated by receptors such as integrins and intracellular proteins that control adhesion to the surrounding extracellular matrix, including focal adhesion kinase (FAK) [17-27]. Another aspect of metastasis is the loss of growth regulation, leading to uncontrolled proliferation, which is regulated by several signaling pathways including PI3K/AKT and mTOR [17, 28-36].

Recently, we described the involvement of the RNAbinding protein (RBP) Staufen1 in Rhabdomyosarcoma (RMS) tumorigenesis [37]. Our findings showed that Staufen 1 is upregulated in RMS and contributes to the pathogenesis by controlling proliferation, migration, and invasion of RMS cells [37]. Historically, Staufen 1 is well known as a multi-functional, double-stranded RBP involved in several key aspects of RNA metabolism including mRNA localization, transport [38, 39], stability [4042], translation [37, 43-47], nuclear export [48, 49], the cell cycle [50] and alternative splicing $[46,49,51]$. These functions are all key for cell physiology and homeostasis, and highlight the fact that misregulation of Staufen1 likely has major detrimental impacts on cell function.

Currently, there is a paucity of information on the impact of Staufen 1 in cancer biology [37, 50, 52-58]. Yet, its implication in several key RNA processes in a variety of cell types indicates that it likely plays pivotal roles in cancerous cells. In this context, its potential function in prostate cancer is unknown. Since the molecular mechanisms underlying metastatic cancer include cell motility, invasion and proliferation of cells, we investigated in the present study how Staufen1 regulates these functions in prostate cancer cells. Here, we report that Staufen 1 is markedly increased in PC. Furthermore, and importantly, Staufen 1 plays differential roles in prostate cancer cells by regulating either cell growth or migration/invasion. Our study highlights for the first time, therefore, the oncogenic role of Staufen1 in PC as well as its potential as a novel biomarker and target for much-needed cancer therapeutics.

\section{Methods}

\section{Constructs and antibodies}

The constructs used were pLKO.1-TRC cloning vector, a gift from David Root (Addgene \#10878), pLKO.1-TRCshStau1 (Clone ID: TRCN0000102306, Clone ID: TRCN0000102308 and Clone ID: TRCN0000102309) (GE Healthcare Life Sciences, Ontario, Canada), pcDH-CMVMCS-EF1-copGFP and pcDH-Stau1-HA (as previously described [49]) pMD2.G (Addgene \#12259) and psPAX2 (Addgene \#12260) were gifts from Didier Trono.

The antibodies used were anti-Staufen1 (ab73478, Abcam, Ontario, Canada), anti-phospho (Ser2448)-mTOR (\#2971, Cell Signaling Technology, Danvers, MA, USA), anti-mTOR (\#2983, Cell Signaling Technology, Danvers, MA, USA), anti-phospho (Try576/577)-FAK (\#3281, Cell Signaling Technology, Danvers, MA, USA), anti-phospho (Tyr397)FAK (\#8556, Cell Signaling Technology, Danvers, MA, USA), anti-FAK (\#13009, Cell Signaling Technology, Danvers, MA, USA), anti-phospho-4E-BP1 (Thr37/46) (\# 9459, Cell Signaling Technology, Danvers, MA, USA), anti-4E-BP1 (\# 9452, Cell Signaling Technology, Danvers, MA, USA), HA.11 clone 16B12 (1:1000; BioLegend, California, USA), anti- $\beta$-actin (\#47778, Santa Cruz Biotechnology, CA, USA), and anti-GAPDH (ab8245, Abcam, Ontario, Canada).

\section{Cell culture, transfection, and Lentivirus production and infection}

Clonetics $^{\mathrm{Tm}}$ Prostate Epithelial cells (PrEC) were cultured using the Prostate Epithelial Cell Medium BulletKit ${ }^{\text {Ta }}$ according to manufacturer instructions (Lonza, NJ, USA). Prostate cancer cells LNCaP (CRL-1740) and PC3 (CRL-1435) were cultured according to manufacturer instructions (American Type Culture Collection, VA, USA). DU145 (HTB-81), were cultured in RPMI 1640 (Wisent Bioproducts, Quebec, Canada) supplemented with 10\% HyClone FBS and 1\% HyClone PenicillinStreptomycin (Thermo Fisher Scientific, Ontario, Canada). HEK 293 T cells (CRL-3216) were cultured according to manufacturer instructions (American Type Culture Collection, VA, USA). All media was supplemented with MycoZap ${ }^{\mathrm{Tm}}$ Prophylactic (Lonza, NJ, USA) and were routinely checked for mycoplasma. All cell cultures were incubated at $37^{\circ} \mathrm{C}, 5 \% \mathrm{CO}_{2}$.

Lentiviral particles were produced in HEK-293 T cells and harvested as previously described [37]. Cells were infected twice with equal volumes of virus and media containing $8 \mu \mathrm{g} / \mathrm{ml}$ Hexadimethrine Bromide (Sigma-Aldrich, Ontario, Canada). Cells were collected $48 \mathrm{~h}$ postsecondary infection. 


\section{Western blotting}

Cells were lysed in RIPA buffer as previously described [45], sonicated and centrifuged $(13,000 \mathrm{rpm}, 10 \mathrm{~min}$ or $1200 \mathrm{~g}, 10 \mathrm{~min}$ for phospho-proteins). Protein concentration was determined with the Bicinchoninic Acid protein assay kit (Thermo Fisher Scientific, Ontario, Canada) and $10-50 \mu \mathrm{g}$ of protein was separated by SDS-PAGE and transferred onto nitrocellulose membranes (Bio-Rad, Ontario, Canada). Membranes were then blocked and incubated with antibodies as previously described [45].

\section{RNA extraction, reverse transcription, and real-time quantitative PCR}

RNA extraction, reverse transcription and qRT-PCR were performed as previously described [45]. Primer sequences were as follows: Staufen1 (fwd 5'-AACGGAAC TTGCCTGTGAAT-3', rev 5'-AGGGGCGGTAACTT CTTCAG-3') and, GAPDH (fwd 5'-AACCACAGTC CATGCCATCAC-3', rev 5' -TCCACCACCCTGTTGC TGTA-3').

\section{Immunofluorescence}

For immunofluorescent staining, cells were fixed for with $4 \%$ formaldehyde in $1 \mathrm{X}$ PBS $\mathrm{pH} 7.4$ for $30 \mathrm{~min}$ and then permeablized with $0.5 \%$ Triton $\mathrm{X}-100$ in $1 \mathrm{X}$ PBS $\mathrm{pH} 7.4$ for $15 \mathrm{~min}$. Cells were then blocked with $10 \%$ fetal bovine serum (FBS) for $1 \mathrm{~h}$ at room temperature. Cells were incubated with the primary antibody diluted in $1 \%$ FBS, $0.1 \%$ Triton X-100 overnight at $4{ }^{\circ} \mathrm{C}$. Next the cells were washed $3 \times 5$ min with $1 \mathrm{X}$ PBS pH 7.4 and then incubated with Alexa secondary antibodies (Invitrogen, Ontario, Canada) for $1-2 \mathrm{~h}$ at room temperature. Cells were washed $3 \times 5$ min with $1 \mathrm{X}$ PBS pH7.4 and then mounted on slides using Vectashield mounting media containing DAPI for staining nuclei (Vector Labs, Ontario, Canada). Cells were visualized by microscopy using a Zeiss AxioImager.M2 microscope.

\section{Proliferation assay and cell cycle analysis}

Cell proliferation was quantified by flow cytometry using 5-bromo-2'-deoxyuridine (BrdU) incorporation. Cells were seeded on $60 \mathrm{~mm}$ culture plates $\left(3 \times 10^{5}\right.$ for DU145 and $\mathrm{LNCaP}$ and $4 \times 10^{5}$ for PC3), infected with CTL or Staufen1-shRNA lentivirus and maintained at 70\% confluency. BrdU $(30 \mu \mathrm{M})$ (Invitrogen, Ontario, Canada) was added to cultures $48 \mathrm{~h}$ post-secondary infection and incubated for $2 \mathrm{~h}$. Cells were stained as previously described [37]. Stained cells were analyzed using the BD FACSCelesta $^{\text {TM }}$ or the BD LSRFortessa ${ }^{\text {TM }}$ flow cytometers. Data analysis was performed using FlowJo software.

\section{Apoptosis assay}

Cells were seeded in $60 \mathrm{~mm}$ culture plates (as stated above), infected with CTL or Staufen1-shRNA lentivirus and maintained at 70\% confluency. Cells were co-stained $48 \mathrm{~h}$ post-secondary infection using the Alexa Fluor 488 Annexin V/Dead Cell Apoptosis Kit with Alexa Fluor. 488 annexin V and PI for Flow Cytometry (Thermo Fisher Scientific, Ontario, Canada) according to manufacturer instructions. Stained cells were analyzed using the BD FACS Celesta $^{\text {TM }}$ or the BD LSRFortessa ${ }^{\text {TM }}$ flow cytometers. Data analysis was performed using FlowJo software.

\section{Motility and invasion assay}

Infected cells $\left(2.5 \times 10^{4}\right)$ were seeded in serum free medium in Corning BioCoat $^{\mathrm{TM}}$ Control Inserts (\#354578) or Corning. GFR Matrigel。 Basement Membrane Matrix Invasion Chambers (\#354480) (VWR International, Ontario, Canada) containing growth medium in the bottom chamber. DU145 and PC3 cells were incubated for 24 and $72 \mathrm{~h}$, respectively. Cells were fixed and stained with the Kwik-Diff ${ }^{\text {tw }}$ Stain (Thermo Fisher Scientific, Ontario, Canada). Cell motility and invasion were assessed according to manufacturer instructions. Five random fields of view were imaged and analyzed using Northern Eclipse Software (NES, Expix Imaging, Ontario, Canada).

\section{Migration assay}

DU145 and PC3 cells were infected with CTL or Staufen1-shRNA lentivirus for $48 \mathrm{~h}$ post-secondary infection and 70ul was seeded into culture inserts (DU145 CTL $8 \times 10^{5}$ cells $/ \mathrm{ml}$; DU145 shStau1 $1 \times 10^{6}$ cells $/ \mathrm{ml}$; PC3 CTL $4 \times 10^{5}$; shStau $14 \times 10^{5}$ cells $/ \mathrm{ml}$ ) to form a confluent monolayer (Ibidi, Munich, Germany). Inserts were removed $24 \mathrm{~h}$ post-seeding and washed with PBS and imaged in real time for up to $24 \mathrm{~h}$ using the Incucyte ZOOM system (Essen Bioscience, MI, USA). The gap was measured using Northern Eclipse Software (NES, Expix Imaging, Ontario, Canada). The average distance at 3 points was calculated. These values were normalized to the \% confluence of cells.

\section{Statistical analysis}

All experiments were performed with a minimum of $n \geq$ 3 biological replicates unless otherwise stated. The data were analyzed using the student's t-test or a one-sample t-test as indicated. Significance was set at $P \leq 0.05$ with ${ }^{*} P \leq 0.05$, ** $P \leq 0.01$, and ${ }^{* * *} P \leq 0.001$. Error bars represent standard deviation (SD).

\section{Results}

Staufen 1 is increased in human prostate Cancer

We examined Staufen1 levels across three separate PC cell lines, namely, PC3, DU145 and LNCaP cells, and compared its expression levels to those observed in normal prostate epithelial cells (PrEC) [59]. These cell lines are commonly used to decipher the mechanisms underlying $\mathrm{PC}$ since they represent both androgen-sensitive and -insensitive entities 
[60-62]. Specifically, PC3 cells were derived from a vertebral bone metastasis site and are classified as prostatic small cell neuroendocrine carcinoma and are androgen-insensitive [60-63]. DU145 cells are also androgen-insensitive and were isolated from brain metastasis of human prostate adenocarcinoma [60-62], while LNCaP cells were established from an androgen-sensitive metastatic lesion of human prostatic adenocarcinoma in the lymph nodes [60-62, 64].

Western blot and RT-qPCR were first performed to analyze Staufen 1 protein and mRNA expression, respectively. Our results show that Staufen 1 is markedly increased $(P<0.05)$ in all cell lines compared to PrEC at both protein and mRNA levels (Fig. 1a, b). In this context, the Human Protein Atlas [65] (v18.1.proteinatlas. org) also identifies Staufen1 as a prognostic factor in human prostate cancer where survival rates decrease in patients with high Staufen1 expression $(N=99)$ compared to those with low Staufen1 expression $(N=395)$ (Protein Atlas; Stau1). ${ }^{1}$ These findings are in agreement with the cell line data presented above and indicate that Staufen1 is also increased in human PC tumours.

\section{Staufen 1 differentially regulates cell growth in prostate Cancer cell lines}

In separate experiments, we assessed the efficiency of our Staufen1 shRNA lentivirus in all three PC cells lines (PC3, DU145, and LNCaP). Control (CTL) or Staufen1targeting shRNA lentiviruses, using a mix of three independent Staufen 1 targeting shRNAs, were used to transduce all three PC cell lines. To confirm Staufen1 knockdown in each cell line, we performed Western blot and immunofluorescence staining using anti-Staufen1 antibodies. Results showed high knockdown efficiency of $\sim 60 \%$ for PC3 and DU145 cells $(P<0.05)$ and $~ 90 \%$ for

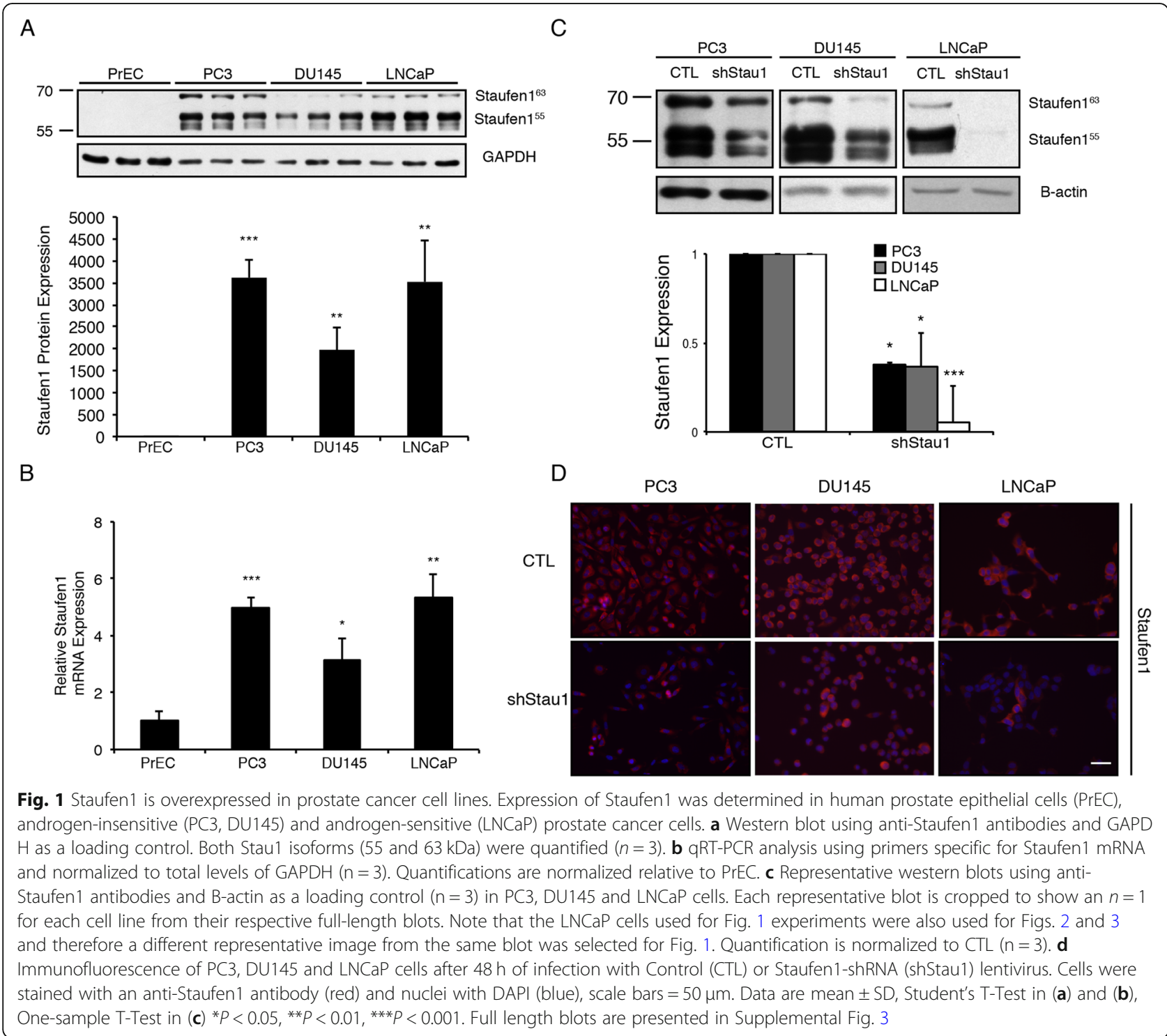


LNCaP cells $(P<0.001)$ (Fig. 1c, d). In our hands, LNCaP cells displayed greater Staufen1 knockdown compared to DU145 and PC3 cells in this transient cell system. This discrepancy may be due to cell type specific properties as described above, which likely contribute to the varying level of transduction efficiencies.

With the establishment of this cell system, we next examined the role of Staufen1 on proliferation across the various PC cell lines. We evaluated cell proliferation using two-parameter flow cytometry to measure bromodeoxyuridine (BrdU) and propidium iodide (PI) staining. In these experiments, Western blot analysis confirmed Staufen 1 knockdown in all cell lines, $\sim 70 \%$ for PC3 and DU145 cells $(P<0.01, P<0.05$, respectively) and $\sim 95 \%$ $(P<0.001)$ for LNCaP cells $48 \mathrm{~h}$ post-infection (Fig. $2 \mathrm{a})$. Following Staufen1 knockdown, LNCaP cells showed an $\sim 50 \%$ decrease in BrdU incorporation, which revealed their lower proliferative capacity $(\mathrm{P}<0.01)$ as compared to CTL (Fig. 2d, g, h). By contrast, cell proliferation was unaffected $(P>0.05)$ in PC3 and DU145 cell lines (Fig. 2b, c, e, f).

Subsequently, dual staining of cells with Annexin V and PI was performed and analyzed by flow cytometry to assess apoptosis in PC cells expressing Staufen1shRNA. Western blot analysis demonstrated reduced Staufen 1 levels in all cell lines with highly efficient knockdown $(P<0.01$; Fig. 3a). Our data collectively show that apoptosis in all PC cell lines was unaffected (Fig. 3b-g). Overall, these data indicate that Staufen1 has differential roles in $\mathrm{PC}$ where it regulates proliferation in LNCaP but not in PC3 or DU145 cells, without impacting apoptosis in either form of PC.

\section{Staufen 1 regulates cell migration and invasion in PC3 and DU145 prostate Cancer cells}

To investigate the possible role of Staufen 1 on invasion and migration properties of PC cells, we carried out transwell invasion and migration assays. We performed these experiments using PC3 and DU145 cell lines since they are derived from prostate cancer metastatic sites $[60,61,66]$ and are highly invasive $[15,66]$. LNCaP cells are non-metastatic $[14,15,67]$, adhere loosely to the substrate, and have the capacity for anchorageindependent proliferation [61]. When cultured at high densities, which is required for these assays, $\mathrm{LNCaP}$ cells detach as sheets [61], making this cell line unreliable for migration and invasion assays.

Western blotting confirmed Staufen1 knockdown ( $80 \%, P<0.01)$ in PC3 and DU145 cells (Fig. 4a). Cells were plated into transwell chambers with either a CTL porous membrane or matrigel-coated membrane. The knockdown of Staufen 1 decreased cell motility by $\sim 40 \%$

\footnotetext{
${ }^{1}$ https://www.proteinatlas.org/ENSG00000124214-STAU1/pathology
}

$(\mathrm{P}<0.01$ and $P=0.06)$ in PC3 and DU145 cells, respectively (Fig. 4b). Next, we assessed invasion in the presence of matrigel and observed that both PC3 and DU145 cell invasion levels were decreased by $\sim 60 \%$ and $\sim 80 \%$, respectively upon Staufen 1 knockdown $(P<0.05$; Fig. $4 \mathrm{~b})$.

Next, we performed migration assays to further evaluate the impact of Staufen1 on PC cell motility and migration. Western blotting confirmed Staufen1 knockdown of greater than 70\% in PC3 cells and DU145 cells $(P<0.001$ and $\mathrm{P}<0.05$, respectively; Fig. 5a). Cells were seeded into culture inserts and cultured for $24 \mathrm{~h}$. A $500 \mu \mathrm{m}$ cell free gap was created by removing the insert which represented time $0 \mathrm{~h}$. Migration of the cells was subsequently evaluated at $4 \mathrm{~h}$-intervals until $100 \%$ gap closure was achieved in CTL cells. Results of these experiments revealed that upon Staufen1 knockdown, PC3 and DU145 cells showed significant $(\mathrm{P}<0.05)$ reductions in migration at almost all time points examined as compared to CTL cells (Fig. 5b, c). The fact that both cell motility and invasion were decreased in PC3 and DU145 cells with Staufen1 knockdown supports the notion that the overexpression of Staufen1 we observed in PC cancer cells (see Fig. 1) translates into marked increases in metastasis capacity.

\section{Staufen 1 differentially regulates tumorigenesis via regulation of signaling pathways across prostate Cancer cell lines}

A key regulator of cell proliferation and growth is the mammalian target of rapamycin (mTOR) [28-30, 32, 34]. The mTOR kinase is central to two distinct complexes, mTORC1 and mTORC2 [68-71]. Upon activation, mTORC1 regulates cell growth and proliferation by modulating protein synthesis via phosphorylation of 4E-BP1 and S6K1 [68-72]. In order to determine whether mTOR is responsible for the reduced cell proliferation observed in LNCaP cells expressing shStau1, we examined the levels of activated mTOR. Western blot analysis confirmed Staufen1 knockdown $(\sim 95 \% ; P<0.001)$ in $\mathrm{LNCaP}$ cells $48 \mathrm{~h}$ post-infection (Fig. 6a). LNCaP cells expressing shStaul showed a decrease $(P<0.05)$ of $\sim 20 \%$ in phosphorylated mTOR relative to total $\mathrm{mTOR}$ as compared to CTL (Fig. 6b). Furthermore, 4E-BP1, a downstream target of mTOR, showed an $\sim 25 \%$ decrease $(\mathrm{P}<0.05)$ in phosphorylation relative to total 4E-BP1, compared to CTL cells (Fig. 6c). In contrast to these data, and in agreement with the lack of a change in proliferation, PC3 and DU145 cell lines, showed no alteration in mTOR activation in response to Staufen 1 knockdown ( $P>0.05$; Supplemental Fig. 1). These data indicate that Staufen 1 alters cell proliferation specifically in the LNCaP cell line via regulation of $\mathrm{mTOR}$ signaling through unknown mechanisms at this time.

The most prevalent and main complication in CRPC progression is bone lesion metastasis [3, 73-76]. Approximately two-thirds of all bone metastases are located 
A
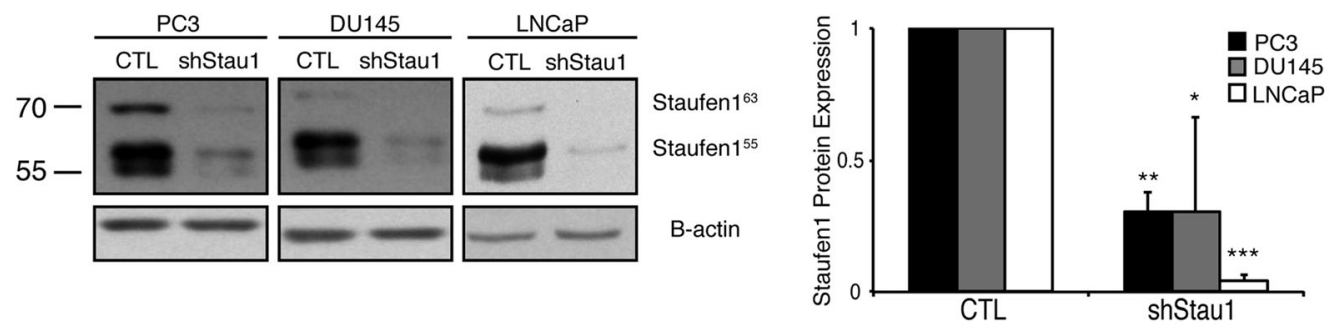

B

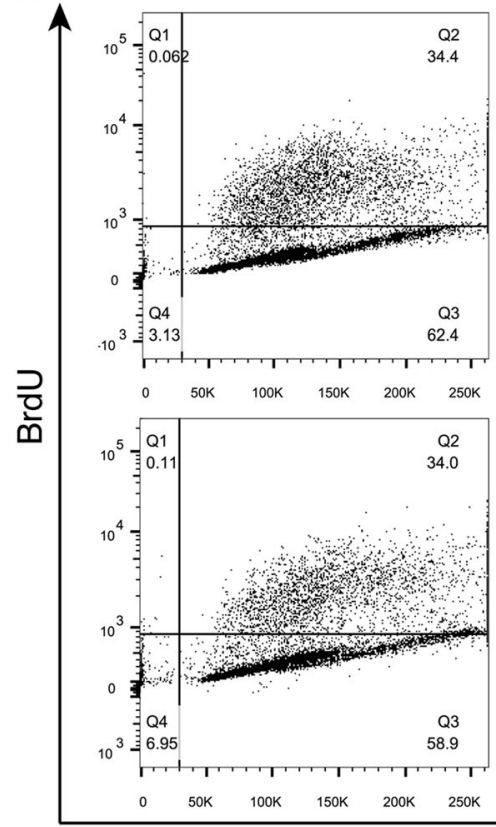

E PC3:
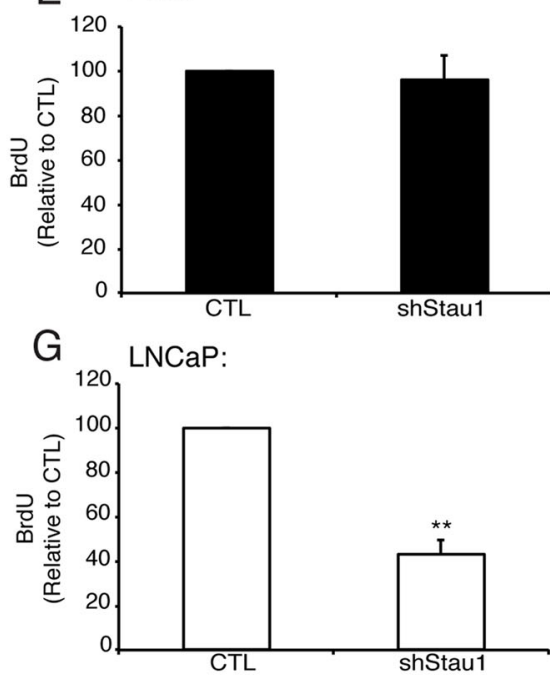

C
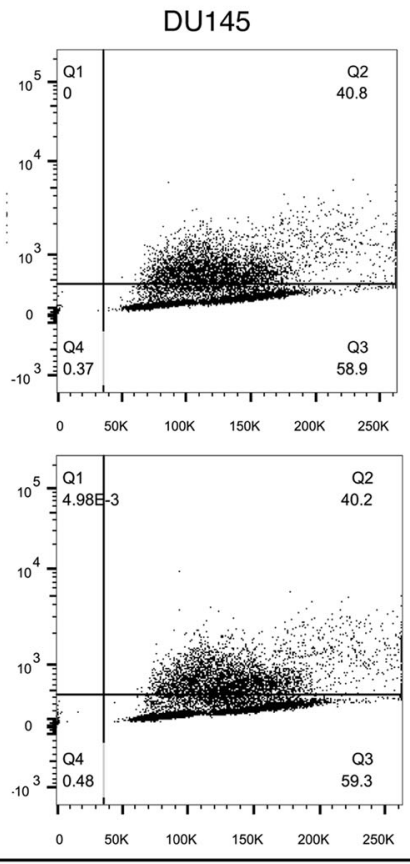

D LNCaP

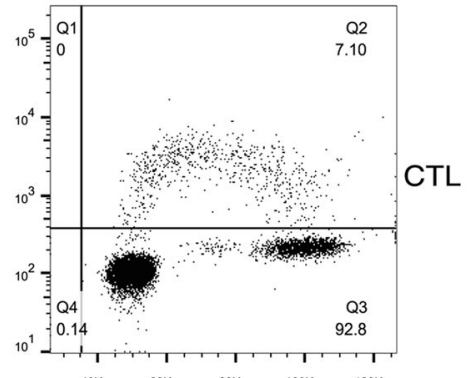

$40 \mathrm{~K} \quad 60 \mathrm{~K} \quad 80 \mathrm{~K} \quad 100 \mathrm{~K} \quad 120 \mathrm{~K}$

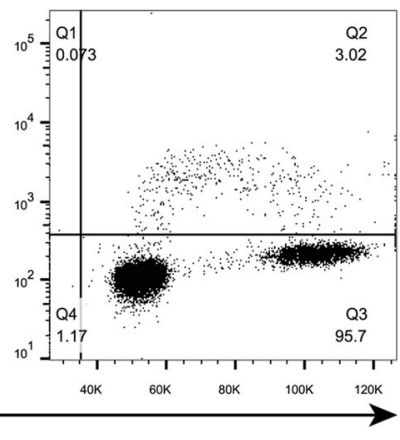

shStau1

PI

F DU145:

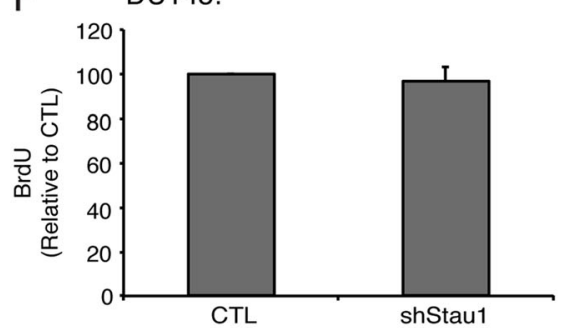

$\mathrm{H}$

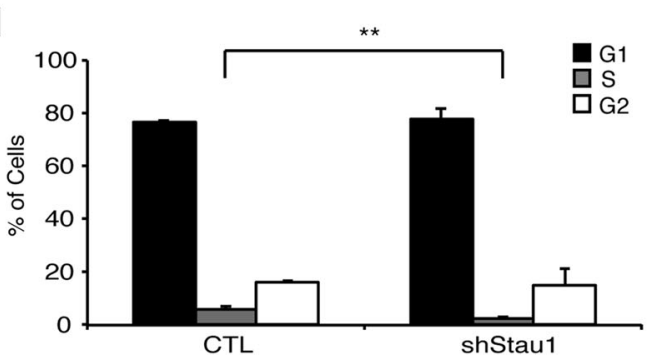

Fig. 2 (See legend on next page.) 


\section{(See figure on previous page.)}

Fig. 2 Staufen 1 regulates the proliferation and cell cycle of LNCaP cells. Analysis of cell proliferation was performed after 48 h of Control (CTL) or Staufen1-shRNA expression (shStau1) in all three PC cell lines. a Representative western blot of Staufen1 expression with B-actin as a loading control in PC3, DU145, and LNCaP cells. Each representative blot is cropped to show an $n=1$ for each cell line from their respective full-length blot. Note that the LNCaP cells used for Fig. 1 experiments were also used for Figs. 1 and 3 and therefore a different representative image from the same blot was selected for Fig. 2. Quantification is represented normalized to CTL $(n=3)$. b-d Proliferation was assessed by two-parameter flow cytometry and representative dot plots following $2 \mathrm{~h}$ of BrdU incorporation and Propidium lodide (PI) staining in PC3, DU145, and LNCaP cells expressing CTL or Staufen1-shRNAs. e- $\mathbf{g}$ Quantification of BrdU incorporation is represented as a percentage relative to CTL in all three PC cell lines $(n=3)$. $\mathbf{h}$ the percentage of the cells in $G 1, S$ and $G 2$ phases are indicated. Data are Mean \pm SD, One-Sample T-Test, *P $<0.05,{ }^{*}$ P $<0.01$, ${ }^{* *} \mathrm{P}<0.001$. Full length blots are presented in Supplemental Fig. 4

in the spine [76]. Hence, we focused our efforts on determining the potential mechanisms by which Staufen 1 regulates cell invasion in PC3 cells, which are derived from a bone metastatic site [60-62]. FAK is involved in the key aspects of the metastatic process and FAK signaling is crucial for focal adhesion turnover by regulating disassembly of focal adhesions, thereby highlighting a key role in cell migration and invasion [19, 77-80]. Following integrin clustering, FAK is recruited to the cytoplasmic portion of the $\beta$ integrin subunits and is subsequently autophosphorylated at tyrosine 397, which causes kinase activation and creates a $\mathrm{SH} 2$ binding site for the protein tyrosine kinase c-Src [81, 82]. Upon adhesion, Src phosphorylates tyrosines 567 and 577 within the kinase domain of FAK to stimulate maximal FAK activity $[81,82]$.

As mentioned above, shStaul expressing PC3 cells showed reduced invasion and migration relative to CTL conditions. Therefore, we examined key members of the FAK signaling family to investigate potential mechanisms by which Staufen 1 impacts cell migration and invasion. Western blot analysis confirmed Staufen 1 knockdown $(\sim 85 \% ; P<0.001)$ in PC3 cells, $48 \mathrm{~h}$ postinfection (Fig. 6d). Cells with reduced Staufen1 expression showed a decrease of $\sim 55 \%(P<0.05)$ in the ratio of phosphorylated Tyr397 FAK/total FAK and 85\% $(P<0.01)$ in phosphorylated Tyr576/577 relative to total FAK, as compared to CTL conditions (Fig. 6e). These data indicate that Staufen 1 overexpression plays a role in the activation of FAK in the metastatic PC3 cell line, thus impacting cell motility.

Next, we attempted to overexpress Staufen1-HA in the knockdown cell lines to determine if ectopic Staufen1 expression could rescue the observed impact of the knockdown on migration and invasion in PC3 and DU145 cell lines. As shown in Supplemental Fig. 2, we were not able to achieve overexpression of Staufen1-HA in the knockdown PC cell lines as the Staufen1-shRNAs likely target both endogenous and overexpressed Staufen1-HA.

\section{Discussion}

The high mortality rate associated with CRPC is a result of the aggressive nature of PC cells in forming metastatic lesions $[6,10,12,13]$. Despite recent advances in our understanding of the underlying molecular mechanisms, prognosis remains poor for advanced PC [5], highlighting the need for additional investigation focused on the progression of CRPC. Our recent work has focused on Staufen1, a multi-functional double-stranded RBP with several roles in post-transcriptional regulation of gene expression [38-40, 42, 43, 45-51, 83, 84]. Multiple lines of evidence show that Staufen 1 has important regulatory roles during skeletal muscle differentiation [41, 42, 45, 85-88] and that it is misregulated in various neuromuscular disorders $[49,51,89,90]$. Its role in cancer biology has only recently begun to emerge, yet its implication in specific cancers including prostate cancer, deserves attention.

Cell motility, invasion and proliferation are key hallmarks of metastatic cancer, and elucidating the molecular mechanisms underlying these tumorigenic properties is crucial for the development of novel therapeutic strategies for these devastating diseases. In the current study, we investigated how Staufen1 regulates motility, invasion and proliferation in commonly studied prostate cancer cells. Our data show that Staufen1 is highly increased in $\mathrm{PC}$ and that this misregulation differentially impacts the various cell lines by regulating either cell growth or migration/invasion. Specifically, we report that Staufen1 regulates the proliferation of $\mathrm{LNCaP}$ cells via the mTOR signaling pathway. Interestingly, mTOR is a protein kinase that controls several anabolic processes required for cell growth and proliferation [71, 72]. Misregulation of mTOR signaling has been previously implicated in various forms of cancer [35, 71, 72, 91, 92]. In PC, 70-100\% of cases of advanced disease are characterized by misregulation of the PI3K/AKT/mTOR signaling pathways [31]. Such misregulation has been associated with resistance to androgen deprivation therapy, disease progression, and poor outcomes [31]. A key aspect of CRPC progression is persistent androgen receptor (AR) signaling [93]. One mechanism by which PC bypasses the need for androgen is through gain-of-function mutations in the androgen signaling pathway [10, 74]. Recent studies have demonstrated a direct link between PI3K/AKT/ mTOR and AR signaling, revealing important cross-talk between these pathways during the development of androgen insensitivity [93]. Altered PI3K/AKT/mTOR signaling affects AR signaling and thus, reduces the 
A
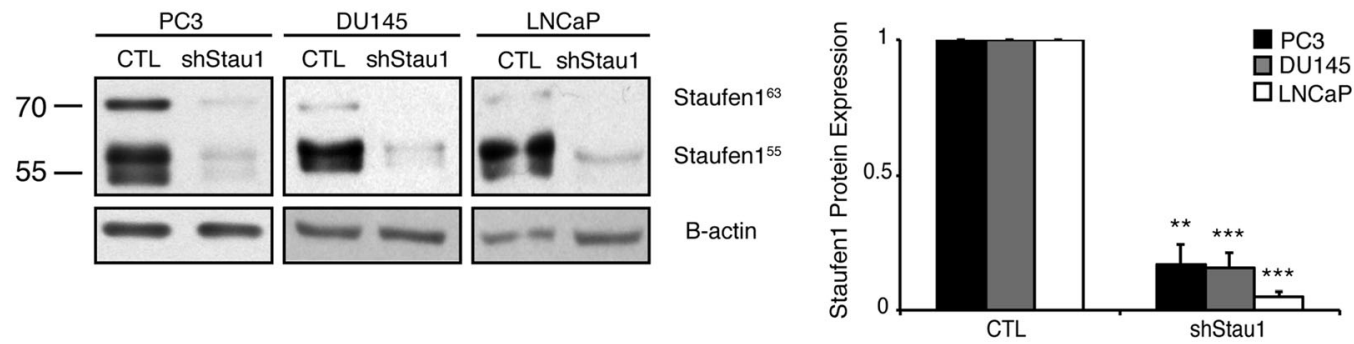

B

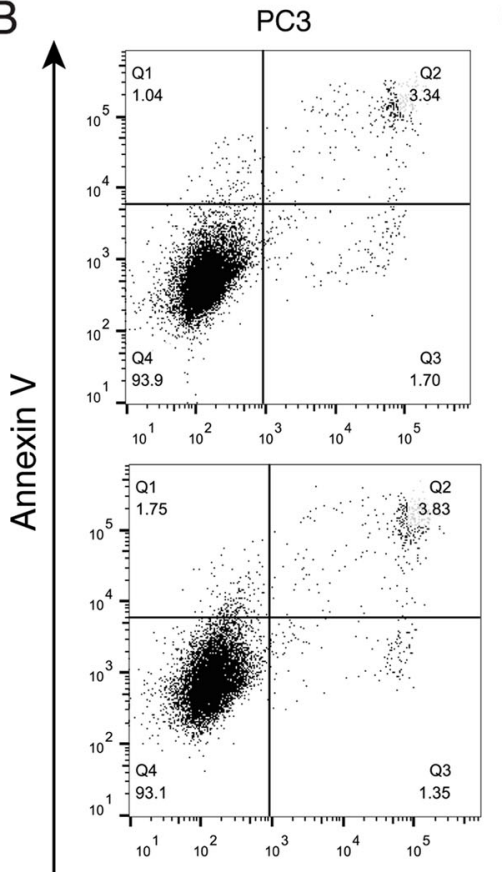

C
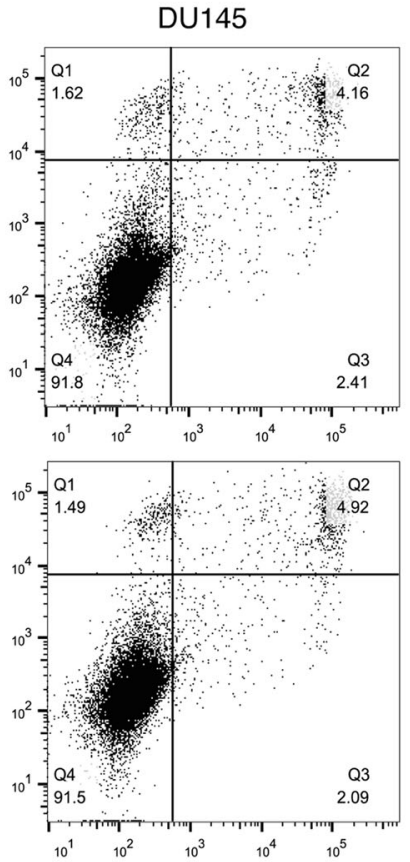

D $\quad$ LNCaP

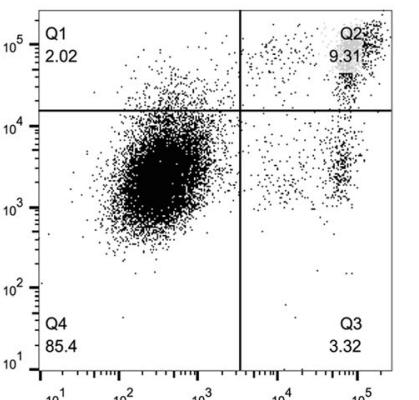

CTL

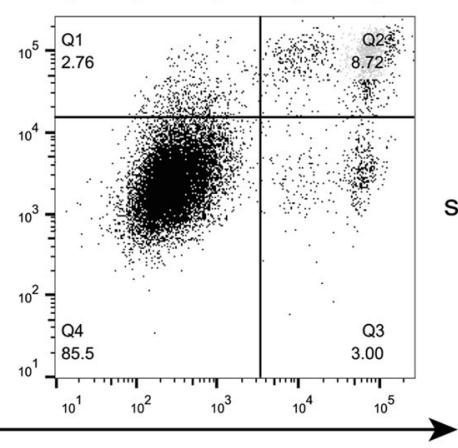

G
E PC3:
F

DU145:
$\mathrm{PI}$

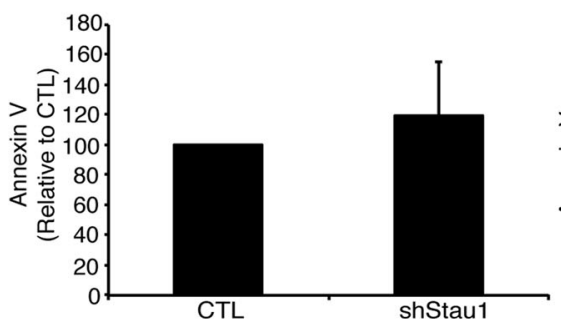

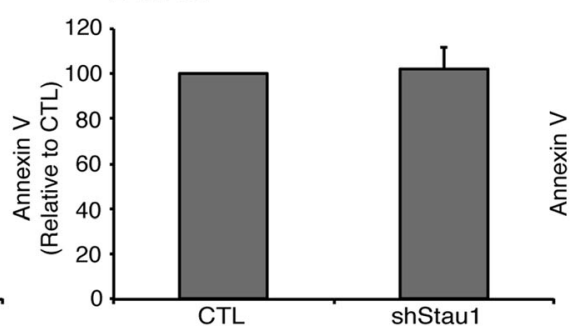

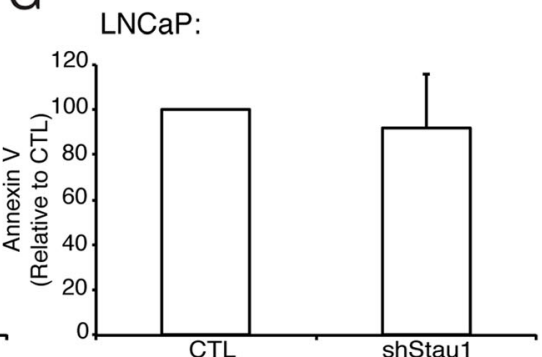

Fig. 3 Staufen1 does not regulate apoptosis in Prostate Cancer cells. Analysis of apoptosis was performed after $48 \mathrm{~h}$ of Control (CTL) or Staufen1shRNA expression (shStau1) in PC cells using Annexin V and Propidium lodide (PI) dual staining. a Representative western blot of Staufen1 expression with B-actin as a loading control in PC3, DU145, and LNCaP cells. Each representative blot is cropped to show an $n=1$ for each cell line from their respective full-length blot. Note that the LNCaP cells used for Fig. 3 experiments were also used for Figs. 1 and 2 and therefore a different representative image from the same blot was selected for Fig. 3. Quantification is represented normalized to CTL $(n=3)$. b-d Apoptosis was assessed by two-parameter flow cytometry and representative dot plots of CTL and Staufen1-shRNA expressing PC3, DU145, and LNCaP cells. e-g Quantification of Annexin V staining is represented as a percentage relative to CTL $(n=3)$. Data are Mean \pm SD, One-Sample T-Test. Full length blots are presented in Supplemental Fig. 5 

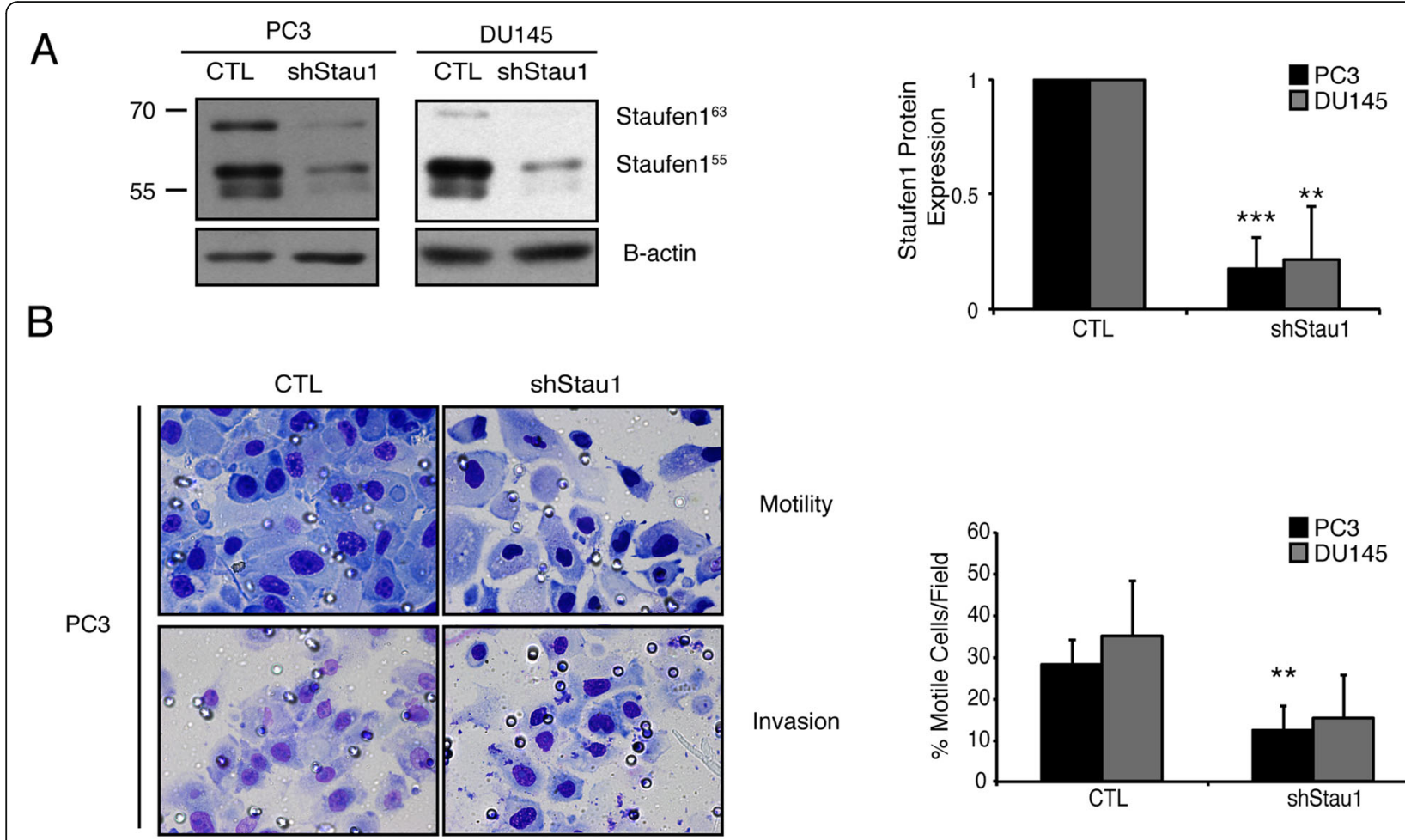

Motility

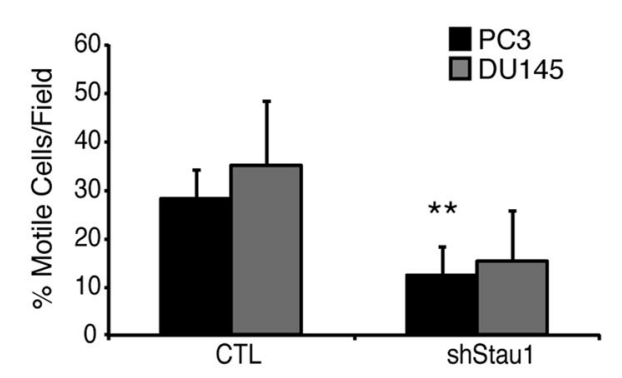

DU145

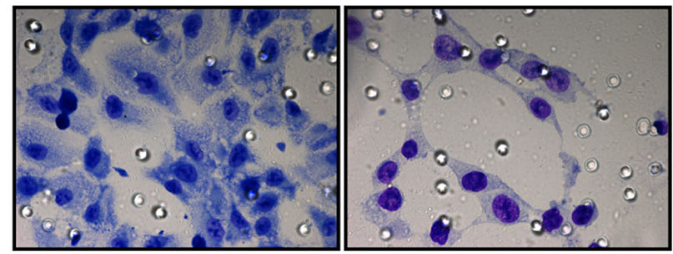

Motility

Invasion

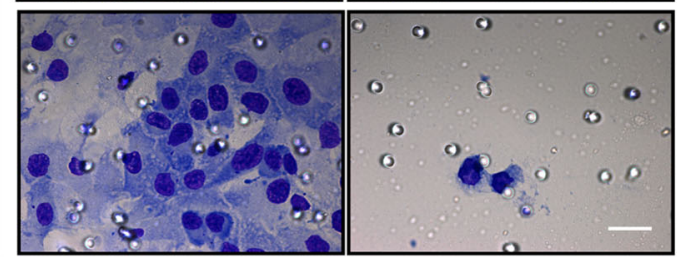

Invasion

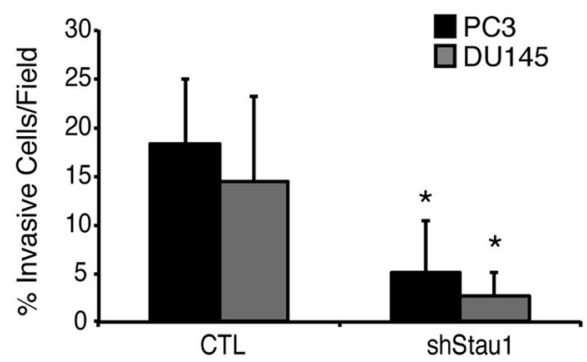

Fig. 4 Staufen 1 knockdown inhibits Prostate Cancer cell invasion and motility. Motility and Invasion assays were performed following $48 \mathrm{~h}$ of Control (CTL) or Staufen1-shRNA (shStau1) expression. a Western blot analysis of Staufen1 expression showing a representative blot of Staufen1 with $\beta$-actin as a loading control in PC3 and DU145 cells. Each representative blot is cropped to show an $n=1$ for each cell line from their respective full-length blot. Note that the DU145 cells used for Fig. 4 were also used for Fig. 5 experiments and therefore a different representative image from the same blot was selected for each figure. Quantification of $n=4$ is represented normalized to CTL. Data are Mean \pm SD, OneSample T-Test, ${ }^{* *} \mathrm{P}<0.01,{ }^{* * *} \mathrm{P}<0.001$. b Cells were seeded into transwell chambers containing membranes coated with or without Matrigel and incubated for $72 \mathrm{~h}$ and $24 \mathrm{~h}$ for PC3 and DU145 cells, respectively. Representative images of cells that passed through the transwell chamber at 40X magnification, scale bar $=20 \mu \mathrm{m}$, are displayed. Average number of cells/field of view is quantified for cell motility (no matrigel) and invasion (matrigel) as a percentage relative to CTL. Quantifications are for all data are $n=4$. Data are Mean \pm SD, Students T-Test, ${ }^{* * P}<<0.01,{ }^{* * * P}<<0.001$. Full length blots are presented in Supplemental Fig. 6

intrinsic need for androgens to drive PC growth, further contributing to castration resistance [93]. Since androgen-insensitive cells, DU145 and PC3, have mutations in the AR, they likely have over-active mTOR signaling, unable to be regulated by Staufen 1 [59, 60, 94].

mTOR is the catalytic subunit for two functionally distinct protein complexes known as mTORC1 and mTORC2 $[71,93]$. Since mTORC1 is hyperactivated in a large subset of cancers, the regulation of mTOR activity is a promising therapeutic target and, accordingly, several small molecules have been developed to inhibit its activity in various forms of cancer [71], including rapalogs and second-generation mTOR inhibitors [95-106]. Altogether, these findings support the notion that regulation of mTOR signaling in PC is a viable therapeutic approach. Our data indicate that Staufen1 plays a key 


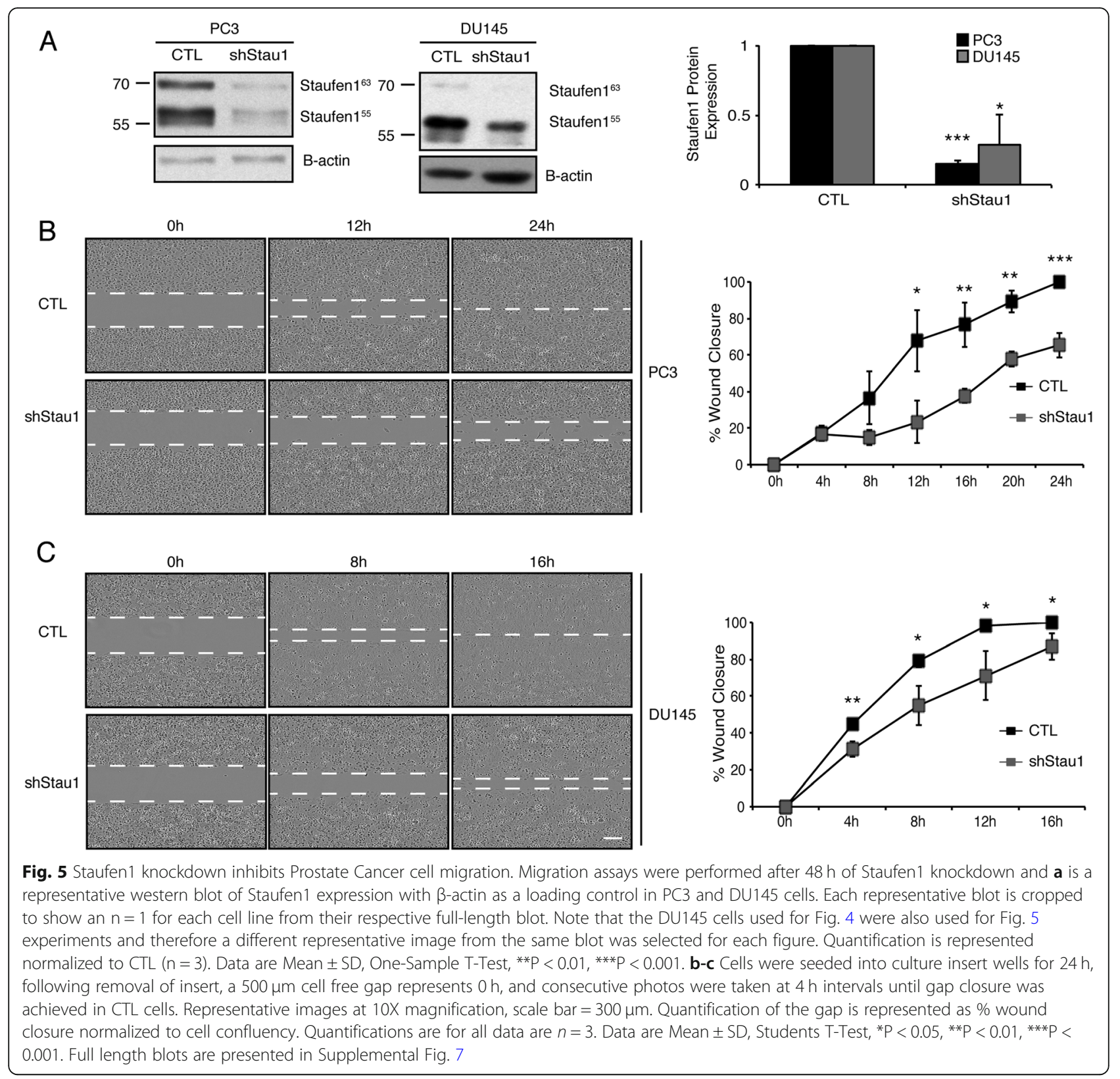

role in the activation of mTOR in LNCaP cells highlighting its potential as a novel therapeutic target to modulate mTOR activation in androgen-sensitive PC.

Conversely, in PC3 cells the knockdown of Staufen1 reduced motility and invasion but not proliferation through decreased activation of FAK. A complication of CRPC is the formation of metastatic lesions, primarily metastasizing to bone $[3,59,60,62,73-76]$. Notably, integrins and FAK signaling have been implicated in metastasis of PC to bone [107]. Cell migration and invasion are essential components of tumour metastasis and focal adhesions that drive metastatic characteristics in malignant cells $[79,107]$. In addition, increased FAK activity and phosphorylation are associated with tumorigenesis in various forms of cancer [77-81]. Here, we demonstrate that Staufen1 regulates the phosphorylation of FAK in bone metastatic PC3 cells, therefore controlling cell invasion and migration properties in our cultured cell systems.

In several forms of cancer, including metastatic PC, FAK expression is upregulated and is associated with poor prognosis due to its role in metastasis and invasion [77, 78, 82, 108-110]. Several lines of evidence indicate that FAK-mediated signaling is involved in the development of tumour malignancy, therefore, several therapeutic approaches have been developed to modulate FAK activity [81]. In agreement with our data that show decreased migration/invasion in parallel to downregulated FAK activity in PC3 cells, several other studies 


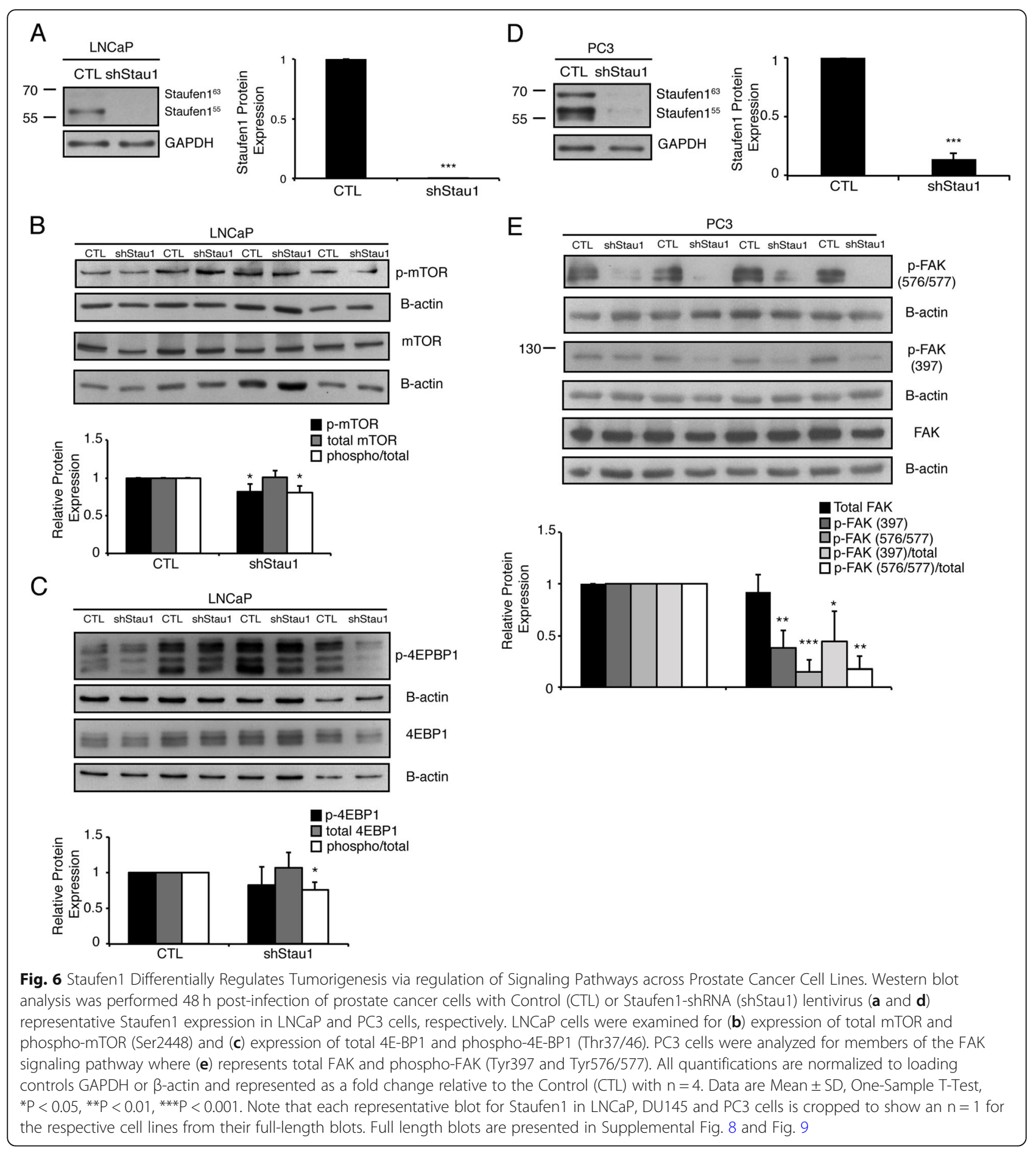

have shown that a reduction in FAK expression and/or activity decreased the migration/invasion of cancer cells, including in PC [111-119]. Taken together with our results, these data further highlight the therapeutic potential of Staufen1 for PC and demonstrate its important function in metastasis of highly invasive PC cells through its regulation of FAK activity. The fact that Sugimoto et al. identified Staufen1-binding sites (SBS) in several mRNAs encoding proteins involved in FAK signaling reinforces the concept of a functional regulatory link between Staufen1 and FAK signaling [46]. More specifically, multiple integrin subunit mRNAs that are upstream of FAK, including A2, A3, A5, B1 and B8, all have SBS [46]. In addition, SHP-2, a protein-tyrosine phosphatase that can dephosphorylate FAK [120], and Src, a protein-tyrosine kinase which phosphorylates FAK 
[121, 122], also contain SBS [46]. These data are in fact well aligned with the known multi-functional nature of Staufen 1 and suggest that Staufen1 regulates FAK signaling through several direct mRNA targets. Based on these observations, it will be important to determine the precise mechanism of action by which Staufen 1 regulates invasion and migration of PC cells through these SBStarget mRNA interactions.

\section{Conclusions}

Given our current and previous findings, as well as the few reports collectively showing the impact of Staufen1 in cell proliferation, apoptosis, migration and invasion, it seems that a clearer picture is beginning to emerge on the key role of Staufen 1 in cancer biology and tumorigenesis. Furthermore, it appears that the misregulation of Staufen1 in cancer cells results in Staufen1 assuming different functions and triggering distinct signaling pathways according to specific disease contexts and cell types. This is perhaps not entirely surprising given the multi-functional nature of Staufen1 in different cells and at different stages of maturation. The complexity related to Staufen1-regulated cellular events, particularly in cancer, clearly warrants further studies to unravel its full potential and relevance as a valid biomarker and novel therapeutic target for a wide array of cancers.

\section{Supplementary Information}

The online version contains supplementary material available at https://doi. org/10.1186/s12885-021-07844-2.

Additional file 1: Supplemental Figure 1. Western blot analysis was performed 48 hours post-infection of prostate cancer cells with Control (CTL) or Staufen1-shRNA (shStau1) lentivirus (A) Staufen1 in DU145 cells, (B) expression of total mTOR and phospho-mTOR (Ser2448) in DU145 cells, (C) expression of total mTOR and phospho-mTOR (Ser2448) in PC3 cells. All quantifications are normalized to loading controls GAPDH or $\beta$ actin and represented as a fold change relative to the Control (CTL) with $\mathrm{n}=4$. Data are Mean $\pm \mathrm{SD}$, ${ }^{*} \mathrm{P}<0.05$, ${ }^{* *} \mathrm{P}<0.01$, ${ }^{* * *} \mathrm{P}<0.001$. Note that each representative blot for Staufen1 in DU145 cells is cropped to show an $n=$ 1 for the respective cell lines from their full-length blots. The level of Staufen1 knockdown for PC3 cells is in Fig. 6d.

Additional file 2: Supplemental Figure 2. Western blot analysis was performed on Control (CTL) and Staufen1-shRNA (shStau1) expressing (A) DU145 and (B) PC3 prostate cancer cell lines that were subsequently infected with lentivirus encoding an empty vector ( $\mathrm{pcDH}$ ) or Staufen1-HA overexpression vector ( $\mathrm{pcDH}$-Staufen1-HA) following 24 and 48-hours post-infection. Western blots for total Staufen1, ectopic Staufen1-HA (HA) with the respective $\beta$-actin as a loading control.

Additional file 3: Supplemental Figure 3. Full length uncropped Western blots for Fig. 1. (A) Western blot using anti-Staufen1 and (B) GAPDH antibodies on PrEC, PC3, DU145 and LNCaP cells $(n=3)$. (C) Full length western blot using anti-Staufen 1 and B-actin antibodies on PC3 cells $(n=3)$. (D) Full length western blot using anti-Staufen1 and (E) Bactin antibodies on LNCaP cells $(n=3)$. (F) Full length western blot using anti-Staufen1 and (G) B-actin antibodies on DU145 cells $(n=3)$.

Additional file 4: Supplemental Figure 4. Full length uncropped Western blots for Fig. 2. (A) Full length western blot using anti-Staufen1 and (B) B-actin antibodies on DU145 and PC3 cells ( $n=3)$. (C) Full length western blot using anti-Staufen1 and (D) B-actin antibodies on LNCaP cells $(n=3)$.

Additional file 5: Supplemental Figure 5. Full length uncropped Western blots for Fig. 3. (A) Full length western blot using anti-Staufen1 and (B) B-actin antibodies on PC3 cells $(n=3)$. (C) Full length western blot using anti-Staufen1 and (D) B-actin antibodies on DU145 cells $(n=3)$. (E) Full length western blot using anti-Staufen 1 and (F) B-actin antibodies on LNCaP cells $(n=4)$.

Additional file 6: Supplemental Figure 6. Full length uncropped Western blots for Fig. 4. (A) Full length western blot using anti-Staufen1 and (B) B-actin antibodies on PC3 cells $(n=4)$. (C) Full length western blot using anti-Staufen1 and (D) B-actin antibodies on DU145 cells ( $n=4)$. Note: DU145 cell lines used are the same as those presented in Supplemental Figure 6, as the same batch of cells were split and used for both sets of experiments.

Additional file 7: Supplemental Figure 7. Full length uncropped Western blots for Fig. 5. (A) Full length western blot using anti-Staufen1 and (B) B-actin antibodies on PC3 cells $(n=3)$. (C) Full length western blot using anti-Staufen1 and (D) B-actin antibodies on DU145 cells $(n=3)$. Note: DU145 cell lines used are the same as those presented in Supplemental Figure 5, as the same batch of cells were split and used for both sets of experiments.

Additional file 8: Supplemental Figure 8. Full length uncropped Western blots for Fig. 6. (A) Full length western blot using anti-Staufen1 and (B) GAPDH antibodies on LNCaP cells $(n=4)$. (C) Full length western blot using anti-mTOR and (D) B-actin antibodies on LNCaP cells $(n=4)$. (E) Full length western blot using anti-phospho-mTOR and (F) B-actin antibodies on LNCaP cells $(n=4)$. (G) Full length western blot using anti4EBP1 and (H) B-actin antibodies on LNCaP cells $(n=4)$. (I) Full length western blot using anti-phospho-4EBP1 and (J) B-actin antibodies on LNCaP cells $(n=4)$.

Additional file 9: Supplemental Figure 9. Full length uncropped Western blots for Fig. 6. (A) Full length western blot using anti-Staufen1 and (B) GAPDH antibodies on PC3 cells ( $n=4)$. (C) Full length western blot using anti-phospho(576/577)-FAK and (D) B-actin antibodies on PC3 cells $(n=4)$. (E) Full length western blot using anti-phospho(397)-FAK and (F) Bactin antibodies on PC3 cells $(n=4)$. (G) Full length western blot using anti-FAK and (H) B-actin antibodies on PC3 cells $(n=4)$.

\section{Abbreviations}

PC: Prostate cancer; PIN: Prostate intraspithelial neoplasia; CRPC: Castrationresistant prostate cancer; FAK: Focal adhesion kinase; RBP: RNA-binding protein; RMS: Rhabdomyosarcoma; PrEC: Prostate epithelial cells; FBS: Fetal bovine serum; BrdU: 5-bromo-2'-deoxyuridine; SEM: Standard error of the mean; RT-qPCR: Real time quantitative PCR; CTL: Control; PI: Propidium iodide; mTOR: Mammalian target of rapamycin; SBS: Staufen-1 binding site; AR: Andogren receptor; shStau1: Staufen-1 shRNA; Ser: Serine; Thr: Threonine; Tyr: Tyrosine

\section{Acknowledgements}

The authors would like to thank John Lunde and Dr. Vera Tang for expert technical expertise.

\section{Authors' contributions}

KAM, TECP and SA performed the experiments. TECP, KAM and BJJ

conceived the project, designed the experiments and wrote the manuscript. All authors reviewed and approved the manuscript.

\section{Funding}

This work was supported in part by operating grants from the Canadian Institutes of Health Research, the Cancer Research Society, and the University of Ottawa, Faculty of Medicine.

\section{Availability of data and materials}

The datasets used and/or analysed during the current study are available from the corresponding author on reasonable request.

Ethics approval and consent to participate Not applicable. 


\section{Consent for publication}

Not applicable.

\section{Competing interests}

The authors declare that they have no competing interests.

Received: 3 August 2020 Accepted: 26 January 2021 Published online: 04 February 2021

\section{References}

1. Chen C, Cao F-H, Li Z-G, Zhang L-G, Liu J, Chen N, et al. Bioinformatics analysis of differentially expressed proteins in prostate cancer based on proteomics data. Onco Targets Ther. 2016;1545. https://doi.org/10.2147/OTT. S98807.

2. Bray F, Ferlay J, Soerjomataram I, Siegel RL, Torre LA, Jemal A. Global cancer statistics 2018: GLOBOCAN estimates of incidence and mortality worldwide for 36 cancers in 185 countries. CA Cancer J Clin. 2018;68:394-424. https:// doi.org/10.3322/caac.21492.

3. Ziaee S, Chu GCY, Huang JM, Sieh S, Chung LWK. Prostate cancer metastasis: roles of recruitment and reprogramming, cell signal network and three-dimensional growth characteristics. Transl Androl Urol. 2015;4:438-54. https://doi.org/10.3978/j.issn.2223-4683.2015.04.10.

4. Luo P, Jiang Q, Fang Q, Wang Y, Wang Z, Yang J, et al. The human positive cofactor 4 promotes androgen-independent prostate cancer development and progression through HIF-1a/B-catenin pathway. Am J Cancer Res. 2019; 9:682-98 http://www.ncbi.nlm.nih.gov/pubmed/31105996.

5. Rawla P. Descriptive epidemiology of prostate Cancer. World J Oncol. 2019; 10:63-89.

6. Lu Q, Liu Z, Li Z, Chen J, Liao Z, Wu W, et al. TIPE2 overexpression suppresses the proliferation, migration, and invasion in prostate Cancer cells by inhibiting PI3K/Akt signaling pathway. Oncol Res Featur Preclin Clin Cancer Ther. 2016;24:305-13.

7. Akinyeke T, Matsumura S, Wang X, Wu Y, Schalfer ED, Saxena A, et al. Metformin targets c-MYC oncogene to prevent prostate cancer. Carcinogenesis. 2013;34:2823-32.

8. Mei W, Lin X, Kapoor A, Gu Y, Zhao K, Tang D. The Contributions of Prostate Cancer Stem Cells in Prostate Cancer Initiation and Metastasis. Cancers (Basel). 2019;11:434.

9. Lima AR, Araújo AM, Pinto J, Jerónimo C, Henrique R, Bastos MDL, et al. Discrimination between the human prostate normal and cancer cell exometabolome by GC-MS. Sci Rep. 2018:8:1-12.

10. Feldman BJ, Feldman D. The Development of Androgen-Independent Prostate Cancer. Nat Rev Cancer. 2001;1:34-45.

11. Nevedomskaya E, Baumgart SJ, Haendler B. Recent advances in prostate Cancer treatment and drug discovery. Int J Mol Sci. 2018;19. https://doi.org/ 10.3390/ijms19051359.

12. Heinlein CA, Chang C. Androgen receptor in prostate cancer. Endocr Rev. 2004;25:276-308.

13. Curran S, Murray Gl. Matrix Metalloproteinases in Tumour Invasion and Metastasis. J Pathol. 1999;308:300-8.

14. Fu Z, Smith PC, Zhang L, Rubin MA, Dunn RL, Yao Z, et al. Effects of Raf kinase inhibitor protein expression on metastasis and progression of human breast Cancer. J Natl Cancer Inst. 2003;95:878-89. https://doi.org/10.1158/ 1541-7786.MCR-08-0403.

15. Liu L, Sun B, Pedersen JN, Aw Yong K-M, Getzenberg RH, Stone HA, et al. Probing the invasiveness of prostate cancer cells in a 3D microfabricated landscape. Proc Natl Acad Sci. 2011;108:6853-6.

16. Klarmann G, Hurt EM, Mathews LA, Zhang X, Duhagon MA, Mistree T, et al. Invasive prostate Cancer cells are tumor initiating cells that have a stem cell-like genomic signature. Clin Exp Metastasis. 2009;26:433-46.

17. Liotta LA, Steeg PS, Stetler-Stevenson WG. Cancer metastasis and angiogenesis: an imbalance of positive and negative regulation. Cell. 1991; 64:327-36.

18. Mukhopadhyay NK, Gordon GJ, Chen CJ, Bueno R, Sugarbaker DJ, Jaklitsch MT. Activation of focal adhesion kinase in human lung cancer cells involves multiple and potentially parallel signaling events. J Cell Mol Med. 2005;9: 387-97.

19. Michael KE, Dumbauld DW, Burns KL, Hanks SK, Garcia AJ. Focal adhesion kinase modulates cell adhesion strengthening via integrin activation. Mol Biol Cell. 2009;20:2508-19.
20. McLean GW, Serrels B, Frame MC, Komiyama NH, Grant SGN, Asano H, et al. Specific deletion of focal adhesion kinase suppresses tumor formation and blocks malignant progression. Genes Dev. 2004;18:2998-3003.

21. Lahlou H, Sanguin-Gendreau V, Zuo D, Cardiff RD, McLean GW, Frame MC, et al. Mammary epithelial-specific disruption of the focal adhesion kinase blocks mammary tumor progression. Proc Natl Acad Sci. 2007;104:20302-7.

22. Horton ER, Humphries JD, Stutchbury B, Jacquemet G, Ballestrem C, Barry ST, et al. Modulation of FAK and Src adhesion signaling occurs independently of adhesion complex composition. J Cell Biol. 2016;212:34964.

23. Howe GA, Xiao B, Zhao H, Al-Zahrani KN, Hasim MS, Villeneuve J, et al. Focal adhesion kinase inhibitors in combination with erlotinib demonstrate enhanced anti-tumor activity in non-small cell lung cancer. PLoS One. 2016; 11:1-20.

24. Johnson TR, Khandrika L, Kumar B, Venezia S, Koul S, Chandhoke R, et al. Focal adhesion kinase controls aggressive phenotype of androgenindependent prostate Cancer. Mol Cancer Res. 2008;6:1639-48.

25. Yoon H, Dehart JP, Murphy JM, Lim STS. Understanding the roles of FAK in Cancer: inhibitors, genetic models, and new insights. J Histochem Cytochem. 2015;63:114-28.

26. Roberts WG, Ung E, Whalen P, Cooper B, Hulford C, Autry C, et al. Antitumor activity and pharmacology of a selective focal adhesion kinase inhibitor, PF562,271. Cancer Res. 2008;68:1935-44.

27. Lin HM, Lee BY, Castillo L, Spielman C, Grogan J, Yeung NK, et al. Effect of FAK inhibitor VS-6063 (defactinib) on docetaxel efficacy in prostate cancer. Prostate. 2018;78:308-17.

28. Schiewer MJ, Den R, Hoang DT, Augello MA, Lawrence YR, Dicker AP, et al. mTOR is a selective effector of the radiation therapy response in androgen receptor-positive prostate cancer. Endocr Relat Cancer. 2012;19:1-12.

29. Edlind MP, Hsieh AC. PI3K - AKT - mTOR signaling in prostate cancer progression and androgen deprivation therapy resistance. October. 2014; 2013:378-86.

30. Tian T, Li X, Zhang J. mTOR signaling in cancer and mtor inhibitors in solid tumor targeting therapy. Int J Mol Sci. 2019;20:1-34.

31. Crumbaker M, Khoja L, Joshua AM. AR signaling and the PI3K pathway in prostate Cancer. Cancers (Basel). 2017;9:1-15.

32. Gao N, Zhang Z, Jiang BH, Shi X. Role of PI3K/AKT/mTOR signaling in the cell cycle progression of human prostate cancer. Biochem Biophys Res Commun. 2003;310:1124-32.

33. Kaarbø M, Løveseter $\varnothing$, Malerød L, Qu S, Lobert VH, Akgul G, Halvorsen T, Maelandsmo GM, Saatcioglu F. PI3K-AKT-mTOR pathway is dominant over androgen receptor signaling in prostate cancer cells. Cell Oncol. 2010;32:1127.

34. Lilis I, Giopanou I, Papadaki H, Gyftopoulos K. The expression of p-mTOR and COUP-TFII correlates with increased lymphangiogenesis and lymph node metastasis in prostate adenocarcinoma. Urol Oncol Semin Orig Investig. 2018;36:311 e27-311.e35.

35. Kremer CL, Klein RR, Mendelson J, Browne W, Samadzedeh LK, Vanpatten K, et al. Expression of mTOR signaling pathway markers in prostate Cancer progression. Prostate. 2006;66:1203-12.

36. Zhu W, Hu X, Xu J, Cheng Y, Shao Y, Peng Y. Effect of PI3K/Akt signaling pathway on the process of prostate Cancer metastasis to bone. Cell Biochem Biophys. 2015;72:171-7. https://doi.org/10.1007/s12013-014-0433-3.

37. Crawford Parks TE, Marcellus KA, Langill J, Ravel-chapuis A, Michaud J, Cowan KN, et al. Novel roles for Staufen1 in Embryonal and alveolar Rhabdomyosarcoma via c-myc- dependent and -independent events. Sci Rep. 2016;2017:1-15. https://doi.org/10.1038/srep42342.

38. Kanai Y, Dohmae N, Hirokawa N. Kinesin transports RNA: isolation and characterization of an RNA-transporting granule. Neuron. 2004;43:513-25.

39. Vessey JP, Macchi P, Stein JM, Mikl M, Hawker KN, Vogelsang P, et al. A loss of function allele for murine Staufen 1 leads to impairment of dendritic Staufen1-RNP delivery and dendritic spine morphogenesis. Proc Natl Acad Sci U S A. 2008:105:16374-9.

40. Kim YK, Furic L, Desgroseillers L, Maquat LE. Mammalian Staufen1 recruits Upf1 to specific mRNA 3'UTRs so as to elicit mRNA decay. Cell. 2005;120: 195-208.

41. Kim Y, Furic L, Parisien M, Major F, DesGroseillers L, Maquat LE. Staufen1 regulates diverse classes of mammalian transcripts. EMBO J. 2007;26:2670-81.

42. Gong C, Kim YK, Woeller CF, Tang Y, Maquat LE. SMD and NMD are competitive pathways that contribute to myogenesis: effects on PAX3 and 
myogenin mRNAs. Genes Dev. 2009;23:54-66. https://doi.org/10.1101/gad. 1717309.

43. Dugré-Brisson S, Elvira G, Boulay K, Chatel-Chaix L, Mouland AJ, DesGroseillers $L$. Interaction of Staufen1 with the $5^{\prime}$ end of mRNA facilitates translation of these RNAs. Nucleic Acids Res. 2005;33:4797-812. https://doi. org/10.1093/nar/gki794.

44. Ricci EP, Kucukural A, Cenik C, Mercier BC, Singh G, Heyer EE, et al. Staufen1 senses overall transcript secondary structure to regulate translation (supplemental). Nat Publ Gr. 2013;21:26-35. https://doi.org/10.1038/nsmb.2739.

45. Ravel-Chapuis A, Crawford TE, Blais-Crépeau M-L, Bélanger G, Richer CT, Jasmin BJ. The RNA-binding protein Staufen1 impairs myogenic differentiation via a c-myc-dependent mechanism. Mol Biol Cell. 2014;25: 3765-78.

46. Sugimoto $Y$, Vigilante A, Darbo E, Zirra A, Militti C, Ambrogio AD, et al. hiCLIP reveals the in vivo atlas of mRNA secondary structures recognized by Staufen 1. Nature. 2015;519:491-4.

47. De Lucas S, Oliveros JC, Chagoyen M, Ortín J. Functional signature for the recognition of specific target mRNAs by human Staufen1 protein. Nucleic Acids Res. 2014;42:4516-26.

48. Elbarbary RA, Li W, Tian B, Maquat LE. STAU1 binding 3' UTR IRAlus complements nuclear retention to protect cells from PKR-mediated translational shutdown. Genes Dev. 2013;27:1495-510.

49. Ravel-Chapuis A, Bélanger G, Yadava RS, Mahadevan MS, DesGroseillers L, Côté $J$, et al. The RNA-binding protein Staufen 1 is increased in DM1 skeletal muscle and promotes alternative pre-mRNA splicing. J Cell Biol. 2012;196:699-712.

50. Boulay K, Ghram M, Viranaicken W, Trépanier V, Mollet S, Fréchina C, et al. Cell cycle-dependent regulation of the RNA-binding protein Staufen1. Nucleic Acids Res. 2014;42:7867-83.

51. Bondy-Chorney E, Crawford Parks TE, Ravel-Chapuis A, Klinck R, Rocheleau L, Pelchat $\mathrm{M}$, et al. Staufen1 regulates multiple alternative splicing events either positively or negatively in DM1 indicating its role as a disease modifier. PLoS Genet. 2016;12:e1005827.

52. Xu TP, Liu XX, Xia R, Yin L, Kong R, Chen WM, et al. SP1-induced upregulation of the long noncoding RNA TINCR regulates cell proliferation and apoptosis by affecting KLF2 mRNA stability in gastric cancer. Oncogene. 2015;34:5648-61.

53. Xu TP, Wang YF, Xiong WL, Ma P, Wang WY, Chen WM, et al. E2F1 induces TINCR transcriptional activity and accelerates gastric cancer progression via activation of TINCR/STAU1/CDKN2B signaling axis. Cell Death Dis. 2017;8: e2837. https://doi.org/10.1038/cddis.2017.205.

54. Ghram M, Bonnet-Magnaval F, Hotea DI, Doran B, Ly S, DesGroseillers L. Staufen 1 is essential for cell-cycle transitions and cell proliferation via the control of E2F1 expression. J Mol Biol. 2020;432:3881-97.

55. Hassine S, Bonnet-Magnaval F, Benoit Bouvrette LP, Doran B, Ghram M, Bouthillette M, et al. Staufen1 localizes to the mitotic spindle and controls the localization of RNA populations to the spindle. J Cell Sci. 2020;133:1-14.

56. Yang C, Zheng J, Liu X, Xue Y, He Q, Dong Y, et al. Role of ANKHD1/ LINC00346/ZNF655 Feedback Loop in Regulating the Glioma Angiogenesis via Staufen 1-Mediated mRNA Decay. Mol Ther - Nucleic Acids. 2020;20:866-78.

57. Liu Z, Chen Z, Fan R, Jiang B, Chen X, Chen Q, et al. Over-expressed long noncoding RNA HOXA11-AS promotes cell cycle progression and metastasis in gastric cancer. Mol Cancer. 2017;16:1-9.

58. Damas ND, Marcatti M, Côme C, Christensen LL, Nielsen MM, Baumgartner $\mathrm{R}$, et al. SNHG5 promotes colorectal cancer cell survival by counteracting STAU1-mediated mRNA destabilization. Nat Commun. 2016;7:1-14. https:// doi.org/10.1038/ncomms13875.

59. Sobel RE, Wang Y, Sadar MD. Molecular analysis and characterization of PrEC, commercially available prostate epithelial cells. Vitr Cell Dev Biol. 2006;42:33-9.

60. Cunningham D, Zongbing $Y$. In vitro and in vivo model systems used in prostate cancer research. J Biol Methods. 2015;2:1-28.

61. Sobel RE, Sadar MD. Cell lines used in prostate cancer research: a compendium of old and new lines - part 1. J Urol. 2005;173:342-59.

62. Namekawa T, Ikeda K, Horie-Inoue K, Inoue S. Application of prostate Cancer models for preclinical study: advantages and limitations of cell lines, patient-derived Xenografts, and three-dimensional culture of patientderived cells. Cells. 2019:8:1-27.

63. Tai S, Sun Y, Squires JM, Zhang H, Oh WK, Liang C, et al. PC3 is a cell line characteristic of prostatic small cell carcinoma. Prostate. 2011;71:1668-79.

64. Horoszewicz JS, Leong SS, Kawinski E, Horoszewicz JS, Leong SS, Kawinski E, et al. LNCaP Model of Human Prostatic Carcinoma LNCaP Model of Human Prostatic Carcinoma. Cancer Res. 1983;43:1809-18.
65. Uhlen M, Zhang C, Lee S, Sjöstedt E, Fagerberg L, Bidkhori G, et al. A pathology atlas of the human cancer transcriptome. Science. 2017;357:1-11.

66. Burke AMYJ, Ali H, O'Connell E, Sullivan FJ, Glynn SA. Sensitivity profiles of human prostate Cancer cell lines to an 80 kinase inhibitor panel. Anticancer Res. 2016;36:633-42.

67. Sumitomo M, Shen R, Walburg M, Dai J, Geng Y, Navarro D, et al. Neutral endopeptidase inhibits prostate cancer cell migration by blocking focal adhesion kinase signaling. J Clin Invest. 2000;106:1399-407.

68. Yu JSL, Cui W. Proliferation, survival and metabolism: the role of PI3KJAKT/ mTOR signalling in pluripotency and cell fate determination. Development. 2016;143:3050-60

69. Mori S, Nada S, Kimura H, Tajima S, Takahashi Y, Kitamura A, et al. The mTOR pathway controls cell proliferation by regulating the FoxO3a transcription factor via SGK1 kinase. PLoS One. 2014;9:1-12.

70. Laplante M, Sabatini DM. Regulation of mTORC1 and its impact on gene expression at a glance. J Cell Sci. 2013;126:1713-9.

71. Cargnello M, Tcherkezian J, Roux PP. The expanding role of mTOR in cancer cell growth and proliferation. Mutagenesis. 2015;30:169-76.

72. Dowling RJO, Topisirovic I, Alain T, Bidinosti M, Fonseca BD, Petroulakis E, et al. mTORC1-Mediated Cell Proliferation, But Not Cell Growth, Controlled by the 4E-BPs. Science. 2010;328:1172-6.

73. Sutherland M, Gordon A, Shnyder SD, Patterson LH, Sheldrake HM. RGDbinding integrins in prostate cancer: expression patterns and therapeutic prospects against bone metastasis. Cancers (Basel). 2012;4:1106-45.

74. Wadosky KM, Koochekpour S. Molecular mechanisms underlying resistance to androgen deprivation therapy in prostate cancer. Oncotarget. 2016;7:124.

75. Zhang S, Gera L, Mamouni K, Li X, Chen Z, Kucuk O, et al. Inhibition of skeletal growth of human prostate cancer by the combination of docetaxel and BKM1644: an aminobisphosphonate derivative. Oncotarget. 2016;7:1-10.

76. Liu P, Liang $Y$, Jiang L, Wang $H$, Wang S, Dong J. CX3CL1/fractalkine enhances prostate cancer spinal metastasis by activating the Src/FAK pathway. Int J Oncol. 2018:53:1544-56.

77. Deramaudt TB, Dujardin D, Noulet F, Martin S, Vauchelles R, Takeda K, et al. Altering FAK-paxillin interactions reduces adhesion, migration and invasion processes. PLoS One. 2014;9:1-13.

78. Hauck CR, Hsia DA, Schlaepfer DD. The focal adhesion kinase - a regulator of cell migration and invasion. Life. 2002;53:115-9.

79. Hsia DA, Mitra SK, Hauck CR, Streblow DN, Nelson JA, llic D, et al. Differential regulation of cell motility and invasion by FAK. J Cell Biol. 2003;160:753-67.

80. Kolli-Bouhafs K, Sick E, Noulet F, Gies JP, De Mey J, Rondé P. FAK competes for Src to promote migration against invasion in melanoma cells. Cell Death Dis. 2014;5:1-10.

81. Tai $Y L$, Chen $L C$, Shen TL. Emerging roles of focal adhesion kinase in cancer. Biomed Res Int. 2015;2015:1-13.

82. Figel S, Gelman IH. Focal adhesion kinase control prostate Cancer progression via intrinsic kinase and scaffolding functions. Anti Cancer Agents Med Chem. 2011:11:607-16.

83. Crawford Parks TE, Ravel-chapuis A, Bondy-chorney E, Renaud J, Côté J, Jasmin BJ. Muscle-specific expression of the RNA-binding protein Staufen1 induces progressive skeletal muscle atrophy via regulation of phosphatase tensin homolog. Hum Mol Genet. 2017;26:1821-38.

84. Ricci EP, Kucukural A, Cenik C, Mercier BC, Singh G, Heyer EE, et al. Staufen1 senses overall transcript secondary structure to regulate translation. Nat Struct Mol Biol. 2013. https://doi.org/10.1038/nsmb.2739.

85. Bélanger G, Stocksley MA, Vandromme M, Schaeffer L, Furic L, DesGroseillers $L$, et al. Localization of the RNA-binding proteins Staufen1 and Staufen2 at the mammalian neuromuscular junction. J Neurochem. 2003;86:669-77.

86. Yamaguchi Y, Oohinata R, Naiki T, Irie K. Stau1 negatively regulates myogenic differentiation in C2C12 cells. Genes Cells. 2008;13:583-92.

87. Yamaguchi Y, Naiki T, Irie K. Stau1 regulates Dvl2 expression during myoblast differentiation. Biochem Biophys Res Commun. 2012;417:427-32.

88. de Morrée A, van Velthoven CTJ, Gan Q, Salvi JS, Klein JDD, Akimenko I, et al. Staufen1 inhibits MyoD translation to actively maintain muscle stem cell quiescence. Proc Natl Acad Sci. 2017:114:E8996-9005.

89. Ravel-Chapuis A, Gunnewiek AK, Belanger G, Crawford Parks TE, Cote J, Jasmin BJ. Staufen1 impairs stress granule formation in skeletal muscle cells from Myotonic dystrophy type 1 patients. Mol Biol Cell. 2016;27:1728-39.

90. Paul S, Dansithong W, Figueroa KP, Scoles DR, Pulst SM. Staufen1 links RNA stress granules and autophagy in a model of neurodegeneration. Nat Commun. 2018;9:E8996-9005. 
91. Hsieh AC, Costa M, Zollo O, Davis C, Feldman ME, Testa JR, et al. Genetic dissection of the oncogenic mTOR pathway reveals Druggable addiction to translational control via 4EBP-elF4E. Cancer Cell. 2010;17:249-61.

92. Forbes SA, Bindal N, Bamford S, Cole C, Kok CY, Beare D, et al. COSMIC: mining complete cancer genomes in the catalogue of somatic mutations in cancer. Nucleic Acids Res. 2011;39(SUPPL. 1):945-50.

93. Hsieh A, Edlind M. PI3K-AKT-mTOR signaling in prostate cancer progression and androgen deprivation therapy resistance. Asian J Androl. 2014;16:378.

94. Van Bokhoven A, Varella-Garcia M, Korch C, Johannes WU, Smith EE, Miller $\mathrm{HL}$, et al. Molecular characterization of human prostate carcinoma cell lines. Prostate. 2003:57:205-25

95. Hudes G, OToole T, Tomczak P, Bodrogi I, Sosman J, Kapoor A, et al. Temsirolimus, interferon Alfa, or both for advanced renal-cell carcinoma. N Engl J Med. 2007:356:2271-81.

96. Motzer RJ, Escudier B, Oudard S, Hutson TE, Porta C, Bracarda S, et al. Efficacy of everolimus in advanced renal cell carcinoma: a double-blind, randomised, placebo-controlled phase III trial. Lancet. 2008;372:449-56.

97. Maira S-M, Stauffer F, Brueggen J, Furet P, Schnell C, Fritsch C, et al. Identification and characterization of NVP-BEZ235, a new orally available dual phosphatidylinositol 3-kinase/mammalian target of rapamycin inhibitor with potent in vivo antitumor activity. Mol Cancer Ther. 2008;7:1851-63.

98. Wallin JJ, Edgar KA, Guan J, Berry M, Prior WW, Lee L, et al. GDC-0980 is a novel class I PI3K/mTOR kinase inhibitor with robust activity in Cancer models driven by the PI3K pathway. Mol Cancer Ther. 2011;10:2426-36.

99. Li J, Kim G, Blenis J. Rapamycin: one drug, many effects an introduction to rapamycin: history and mechanism of action. Cell Metab. 2014;19:373-9. https://doi.org/10.1016/j.cmet.2014.01.001.

100. Yu K, Shi C, Toral-Barza L, Lucas J, Shor B, Kim JE, et al. Beyond rapalog therapy: preclinical pharmacology and antitumor activity of WYE-125132, an ATP-competitive and specific inhibitor of mTORC1 and mTORC2. Cancer Res. 2010;70:621-31.

101. Falcon BL, Barr S, Gokhale P, Chou J, Fogarty J, Depeille P, et al. Reduced VEGF production, angiogenesis, and vascular regrowth contribute to the antitumor properties of dual mTORC1/mTORC2 inhibitors. Cancer Res. 2011; 71:1573-83.

102. Benjamin D, Colombi M, Moroni C, Hall MN. Rapamycin passes the torch: a new generation of mTOR inhibitors. Nat Rev Drug Discov. 2011;10:868-80. https://doi.org/10.1038/nrd3531.

103. García-Martínez JM, Alessi DR, Moran J, Clarke RG, Gray A, Cosulich SC, et al. Ku-0063794 is a specific inhibitor of the mammalian target of rapamycin (mTOR). Biochem J. 2009;421:29-42.

104. Nakabayashi M, Werner L, Courtney KD, Buckle G, Oh WK, Bubley GJ, et al. Phase II trial of RAD001 and bicalutamide for castration-resistant prostate cancer. BJU Int. 2012;110:1729-35.

105. Templeton AJ, Rothermundt C, Gillessen S, Dutoit V, Dietrich P-Y, Cathomas $R$, et al. Phase 2 trial of single-agent everolimus in chemotherapy-naive patients with castration-resistant prostate cancer (SAKK 08/08). Eur Urol. 2013:64:150-8

106. Statz CM, Patterson SE, Mockus SM. mTOR inhibitors in castration-resistant prostate Cancer: a systematic review. Target Oncol. 2017;12:47-59. https:// doi.org/10.1007/s11523-016-0453-6.

107. Hensley PJ, Desiniotis A, Wang C, Stromberg A, Chen CS, Kyprianou N. Novel pharmacologic targeting of tight junctions and focal adhesions in prostate cancer cells. PLoS One. 2014;9:150-8.

108. Zhou J, Yi Q, Tang L. The roles of nuclear focal adhesion kinase (FAK) on Cancer: a focused review. J Exp Clin Cancer Res. 2019;38:1-11.

109. Zeng ZZ, Jia Y, Hahn NJ, Markwart SM, Rockwood KF, Livant DL. Role of focal adhesion kinase and phosphatidylinositol 3'-kinase in integrin fibronectin receptor-mediated, matrix metalloproteinase-1-dependent invasion by metastatic prostate cancer cells. Cancer Res. 2006;66:8091-9.

110. Yang D-J, Wang X-L, Ismail A, Ashman CJ, Valori CF, Wang G, et al. PTEN regulates AMPA receptor-mediated cell viability in iPS-derived motor neurons. Cell Death Dis. 2014;5:e1096.

111. Slack JK, Stoker CE, Parsons JT, Adams RB, Rovin JD, Bissonette EA Alterations in the focal adhesion kinase/Src signal transduction pathway correlate with increased migratory capacity of prostate carcinoma cells. Oncogene. 2001;20:1152-63.

112. Huang YT, Lee LT, Lee PPH, Lin YS, Lee MT. Targeting of focal adhesion kinase by flavonoids and small-interfering RNAs reduces tumor cell migration ability. Anticancer Res. 2005;25 3 B:2017-25.
113. Slack-Davis JK, Martin KH, Tilghman RW, Iwanicki M, Ung EJ, Autry C, et al. Cellular characterization of a novel focal adhesion kinase inhibitor. J Biol Chem. 2007;282:14845-52.

114. Qing S, Hjelmeland AB, Keir ST, Song L, Wickman S, Dowdy J, et al. A novel low-molecular weight inhibitor of focal adhesion kinase, TAE226, Inhibits Glioma Growth. Mol Carcinog. 2007:46:488-96.

115. Tanjoni I, Walsh C, Uryu S, Tomar A, Nam J-O, Mielgo A, et al. PND-1186 FAK inhibitor selectively promotes tumour cell apoptosis in three-dimensional environments. Cancer Biol Ther. 2010:9:764-77.

116. Walsh C, Tanjoni I, Uryu S, Tomar A, Nam J, Luo H, et al. Oral delivery of PND-1186 FAK inhibitor decreases tumor growth and spontaneous breast to lung metastasis in pre-clinical models. Cancer Biol Ther. 2010;9:778-90.

117. Stokes JB, Adair SJ, Slack-Davis JK, Walters DM, Tilgham RW, Hershey ED, et al. Inhibition of focal adhesion kinase by PF-562,271 inhibits the growth and metastasis of pancreatic Cancer concomitant with altering the tumor microenvironment. Mol Cancer Ther. 2011;10:2135-45.

118. Golubovskaya V, Sumbler B, Ho B, Yemma M, Cance W. MiR-138 and MiR135 directly target focal adhesion kinase, inhibit cell invasion, and increase sensitivity to chemotherapy in Cancer cells. Anti Cancer Agents Med Chem. 2014;14:18-28.

119. Duxbury MS, Ito H, Zinner MJ, Ashley SW, Whang EE. Focal adhesion kinase gene silencing promotes anoikis and suppresses metastasis of human pancreatic adenocarcinoma cells. Surgery. 2004;135:555-62.

120. Yu DH, Qu CK, Henegariu O, Lu X, Feng GS. Protein-tyrosine phosphatase Shp-2 regulates cell spreading, migration, and focal adhesion. J Biol Chem. 1998:273:21125-31.

121. Huveneers S, Danen EHJ. Adhesion signaling - crosstalk between integrins. Src and Rho J Cell Sci. 2009;122:1059-69.

122. Mitra SK, Schlaepfer DD. Integrin-regulated FAK-Src signaling in normal and cancer cells. Curr Opin Cell Biol. 2006;18:516-23.

\section{Publisher's Note}

Springer Nature remains neutral with regard to jurisdictional claims in published maps and institutional affiliations.

Ready to submit your research? Choose BMC and benefit from:

- fast, convenient online submission

- thorough peer review by experienced researchers in your field

- rapid publication on acceptance

- support for research data, including large and complex data types

- gold Open Access which fosters wider collaboration and increased citations

- maximum visibility for your research: over $100 \mathrm{M}$ website views per year

At $\mathrm{BMC}$, research is always in progress.

Learn more biomedcentral.com/submission 